\title{
Allelopathic Activity of Strigolactones on the Germination of Parasitic Plants and Arbuscular Mycorrhizal Fungi Growth
}

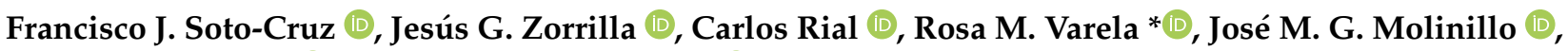 \\ José M. Igartuburu (D) and Francisco A. Macías *(D)
}

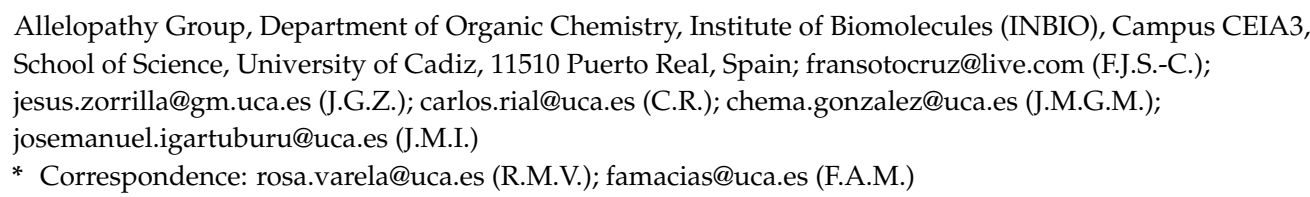

Citation: Soto-Cruz, F.J.; Zorrilla, J.G.; Rial, C.; Varela, R.M.; Molinillo, J.M.G.; Igartuburu, J.M.; Macías, F.A. Allelopathic Activity of Strigolactones on the Germination of Parasitic Plants and Arbuscular Mycorrhizal Fungi Growth. Agronomy 2021, 11, 2174. https://doi.org/10.3390/ agronomy11112174

Academic Editors: Natividad Chaves Lobón, Juan Carlos Alías Gallego and Sara Rodrigo

Received: 8 October 2021

Accepted: 26 October 2021

Published: 28 October 2021

Publisher's Note: MDPI stays neutral with regard to jurisdictional claims in published maps and institutional affiliations.

Copyright: (c) 2021 by the authors. Licensee MDPI, Basel, Switzerland. This article is an open access article distributed under the terms and conditions of the Creative Commons Attribution (CC BY) license (https:// creativecommons.org/licenses/by/ $4.0 /)$.

\begin{abstract}
Strigolactones (SLs) are a prime example of allelochemicals, promoting parasitic plant germination and certain hyphal branching factors associated to the growth of symbiotic arbuscular mycorrhizal fungi (AMF). However, the study of SLs is complex, and various issues have yet to be studied in depth. This review intends to provide an overview of the works that have been conducted on the identification, isolation, and evaluation of the allelopathic activity of natural canonical and non-canonical SLs on parasitic weeds and AMF growth. These topics were related with their application in agriculture through trap crops, suicidal germination or intercropping strategies. The high applicability of SLs in agriculture, for example, as preventing herbicides for parasitic weed control, has increased the interest for these compounds and the number of research articles published. This review updates and discusses the last findings in this field, with special emphasis in the results published since 2015, using tables and graphs to summarize and discuss that information. The promising results and conclusions obtained from the bioassays herein presented provide a good reason to encourage and support further research works on these natural products, which must also consider the disadvantages or current limitations that SLs present.
\end{abstract}

Keywords: allelopathy; phytochemistry; strigolactones; stimulant germinators; parasitic plants; arbuscular mycorrhizal fungi; herbicides

\section{Introduction}

Allelopathy is a mode of communication given in nature among living organisms by releasing chemical compounds that generate changes in those organisms that interact with them. In the case of plants, the release can occur directly through the aerial parts (by leaching or volatilization), and the roots, whose exudates are the source of the most known allelochemicals [1] (commonly auxins, cytokinins, strigolactones, jasmonates, salicylates and abscisic acid [2]). Some examples of recent studies on allelopathy can be those that have proven the inhibitory effects of mangrove condensed tannins on dominant species in a Chinese ecosystem [3]; the phytotoxic study of some allelochemicals released by Thapsia garganica leaves to control lettuce weeds [4]; or the identification and study of the mode of action of menthone as the key active allelochemical of mint essential oils [5].

Among all the types of structures that allelochemicals present, this review focuses on the phytohormones known as strigolactones (SLs), and how they act as such to elicit the germination of parasitic plants, as well as to promote the growth of symbiotic arbuscular mycorrhizal fungi (AMF). These are the two main allelopathic bioactivities studied for SLs. This review also provides relevant information on the isolation sources of SLs. Both the isolation and bioactivities are described in a straightforward way, using tables and graphs to summarize the information provided by numerous studies. 
The review by Cavar et al. (2015) [6] gathered these kinds of data in tables for the first time, our review, in some way, is a continuation and extension of this previous one. Therefore, this review, together with Ćavar et al's, provides easily accessible information on the isolation sources of SLs, as well as on the activity levels in parasitic weed germination and AMF growth bioassays. Due to the relevance of the topic of SLs, there are several other reviews on SLs in the literature, but none of them cover the same information with the same approach on allelopathy or data processing. Throughout our review, we highlighted other relevant reviews in the field in order to furnish references to expand the information provided herein. Our bibliography was selected for these purposes from the database SciFinder by combining the keywords "strigolactones", "isolation of strigolactones", "stimulant germinators", and "arbuscular mycorrhizal fungi growth". The critical reading of the resulting articles denoted the complexity of the topic, and how necessary it is to combine the contributions of chemists, (micro)biologists, agronomists, etc.

\subsection{Structures of Strigolactones}

SLs are a family of natural products commonly classified in two categories according to their structures. The first are canonical SLs, characterized by a main tricyclic scaffold (ABC rings) bonded to a methyl furanone (D-ring) via enol ether bond from the C-ring (a $\gamma$-lactone). The second category comprises the non-canonical SLs, which lacks some $\mathrm{ABC}$ rings, but still present a methyl furanone as D-ring bonded to the main structure via enol ether bond. The moiety defined by this D-ring and the enol ether bond has been highlighted by multiple studies as the fundamental fragment regarding the activity of SLs.

With regard to their biosynthesis, it should be noted that SLs derive from carotenoids, which derive from the condensation of two molecules of geranylgeranyl diphosphate (Scheme 1). The non-canonical SL named carlactone is the first intermediate containing a methyl furanone, and it has been suggested to be the biosynthetic precursor of canonical SLs [7]. Detailed descriptions of SLs biosynthesis can be consulted in recent reviews [8-11], where aspects that are still unknown in this area are highlighted.

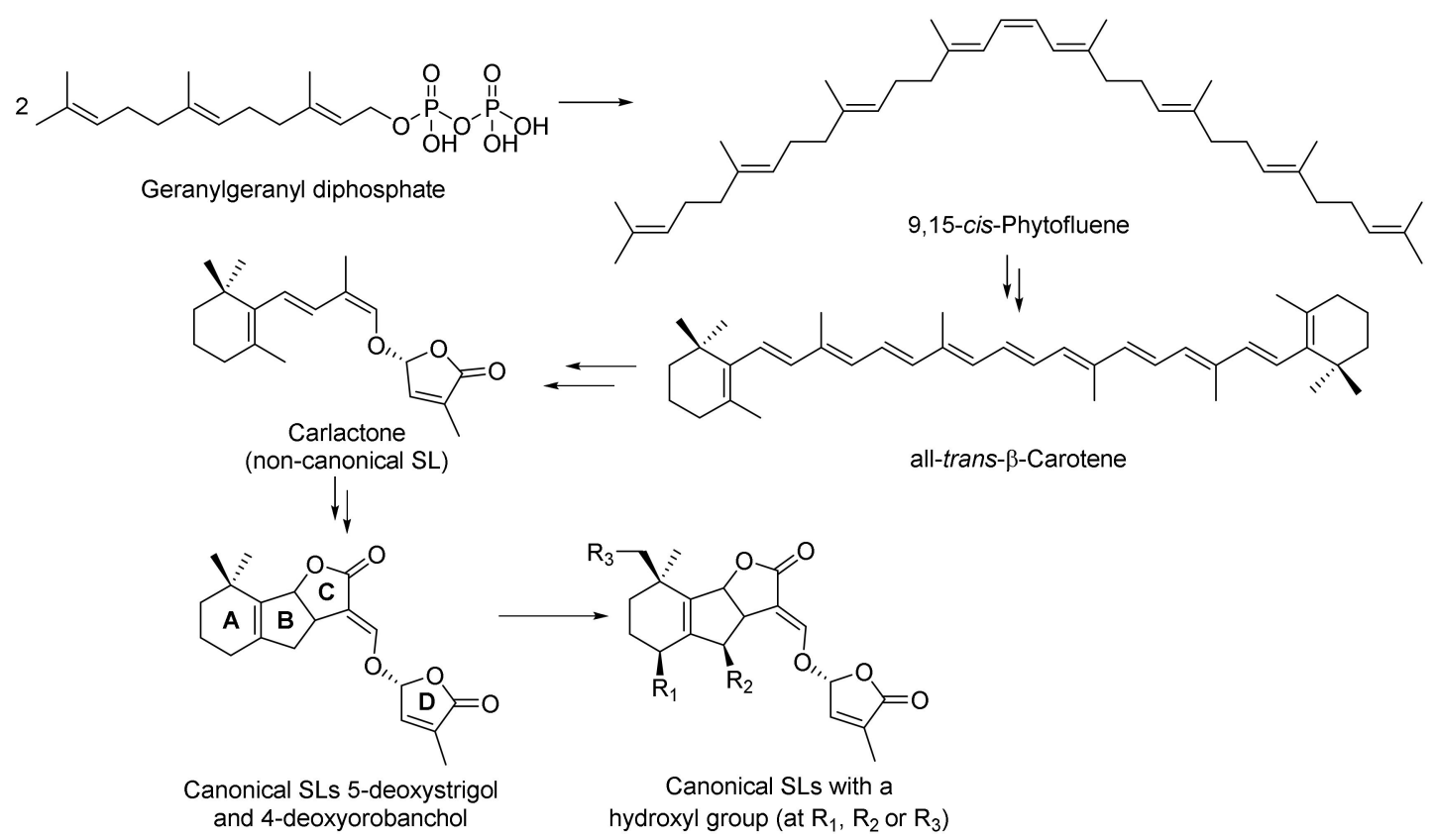

Scheme 1. General route proposed for the biosynthesis of strigolactones.

According to the aforementioned classification method, 23 canonical (Figure 1) and 18 non-canonical (Figure 2) SLs were identified from different plant species. As is shown throughout this review, both types possess relevant allelopathic activities. 


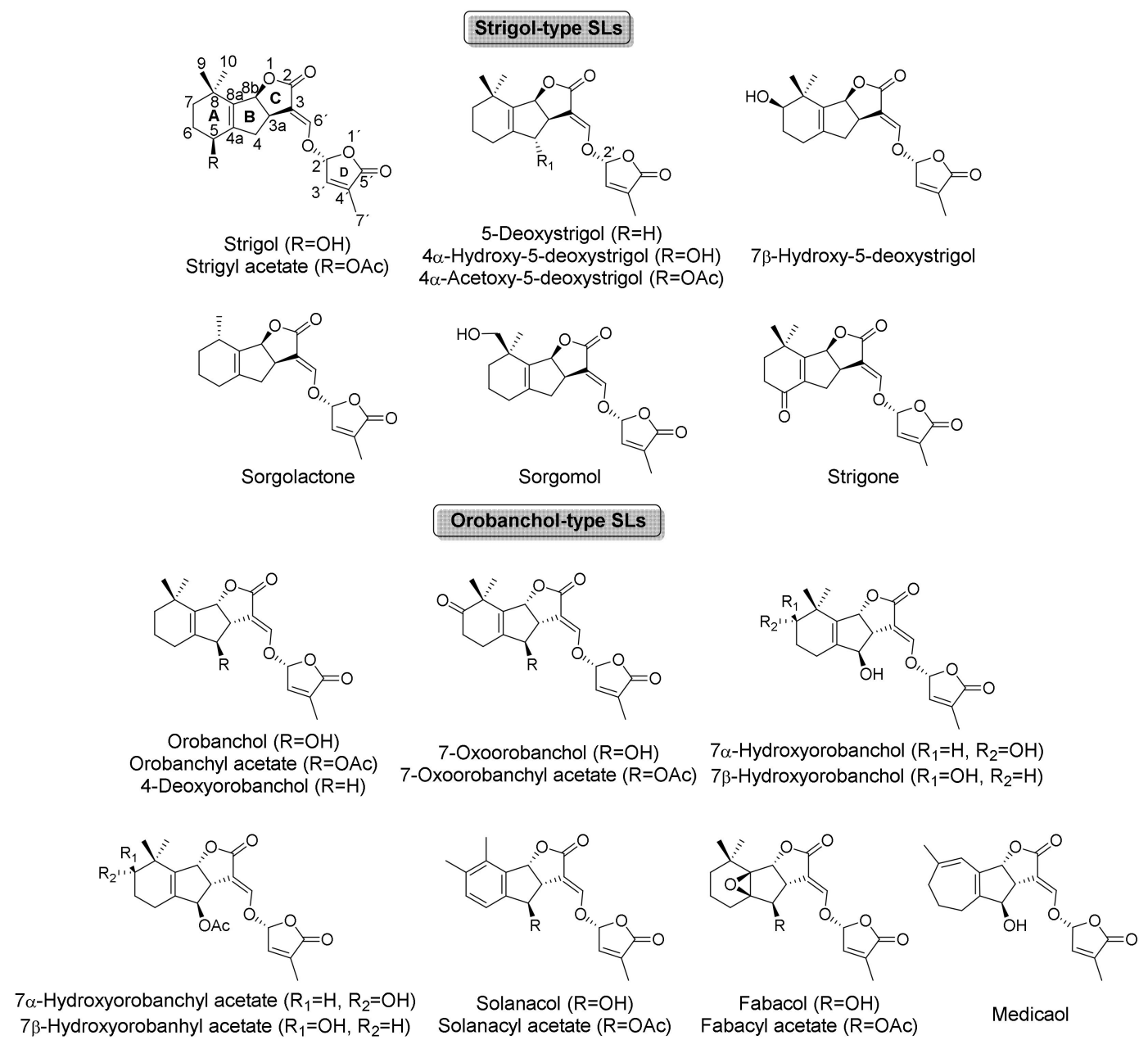

Figure 1. Canonical strigolactones.

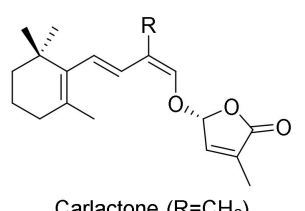

Carlactone $\left(\mathrm{R}=\mathrm{CH}_{3}\right)$ Carlactonoic acid $(\mathrm{R}=\mathrm{COOH})$ Methyl carlactonoate $\left(\mathrm{R}=\mathrm{COOCH}_{3}\right)$<smiles>[R]C(/C=C/C1=C(C)CCCC1(C)CO)=C\OC1C=C(C)C(=O)O1</smiles>

16-Hydroxycarlactone $\left(\mathrm{R}=\mathrm{CH}_{3}\right)$ 16-Hydroxycarlactonoic acid $(\mathrm{R}=\mathrm{COOH})$ Methyl 16-hydroxycarlactonoate $\left(\mathrm{R}=\mathrm{COOCH}_{3}\right)$<smiles>[R]C(/C=C/C1=C(C)CC(O)CC1(C)C)=C\OC1C=C(C)C(=O)O1</smiles>

3-Hydroxycarlactone $\left(\mathrm{R}=\mathrm{CH}_{3}\right)$ 3-Hydroxycarlactonoic acid $(\mathrm{R}=\mathrm{COOH})$

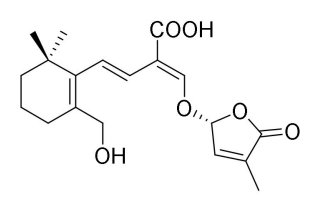

18-Hydroxycarlactonoic acid<smiles>[R]C(/C=C/C1=C(C)C(O)CCC1(C)C)=C\OC1C=C(C)C(=O)O1</smiles>

4-Hydroxycarlactone $\left(\mathrm{R}=\mathrm{CH}_{3}\right)$ 4-Hydroxycarlactonoic acid $(\mathrm{R}=\mathrm{COOH})$ Methyl 4-hydroxycarlactonoate $\left(\mathrm{R}=\mathrm{COOCH}_{3}\right)$<smiles>CC(=O)C(C=C[C@H]1C(C)=CC(=O)CC1(C)C)=CO[C@H]1C=C(C)C(=O)O1</smiles>

Heliolactone

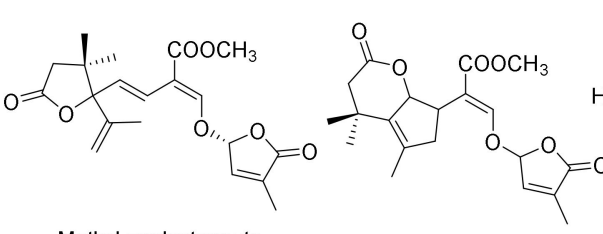

Methyl zealactonoate (also zealactone)<smiles>CC1=CC(O/C=C(/C=C/C2=C(C)CCCC2(C)C)C(=O)OCO)OC1=O</smiles>

Hydroxymethyl carlactonoate

Figure 2. Non-canonical strigolactones. 


\subsection{Milestones on the Isolation and Study of Strigolactones}

Strigol and strigyl acetate were the first SLs isolated from plant material, by Cook et al. (1966) [12] from cotton (Gossypium hirsutum) exudates, a non-host plant. Strigol at low concentrations proved to be actively eliciting the germination of some species of the parasitic weed genera Striga and Orobanche $[6,12,13]$ which promoted the study of SLs for the development of new herbicides based on natural products.

The simplest canonical SL isolated to date, 5-desoxystrigol, was the first SL for which the ability to stimulate AMF branching was corroborated, which was in 2005 [14]. The relevance of this discovery lies in the absence of previous references that support the possible purposes or benefits that SLs production provides to plants. Furthermore, in 2008 , the endogenous hormonal activity of SLs was discovered, confirming their ability to inhibit shoot branching in planta. Thus, SLs were more than communication chemicals with parasitic weeds and AMF $[15,16]$. With these two discoveries, the interest for this family of compounds increased, and SLs began to be isolated and identified in both host and non-host plants, and the list of new SLs increased within a few years. The evolution in the isolation of new SLs is detailed in different reviews, serving as examples those of Ćavar et al. (2015) [6] or Prandi and McErlean (2019) [17]. Though the present review is focused on natural SLs, it should be noted that numerous studies have developed the synthesis of SLs and their stereoisomers, or structural analogues and mimics, notably expanding the variety of SLs and their applicability as agrochemicals and drugs.

Special milestones were also the correction of the first structures suggested for orobanchyl acetate and orobanchol, being the C-ring stereochemistry, the most relevant point. They were wrongly defined due to the structural complexity of SLs, compounded by the small isolated amounts, low stability and, especially, for the limited technical means of the time on structural characterization. Orobanchyl acetate was wrongly defined as alectrol (Figure 3), being corrected 16 years after its first isolation [18]. Figure 3 also shows two previous wrong structures suggested for orobanchol, whose correction was detailed by Zwanenburg et al. (2016) [19]. Both corrections should be taken into account when reading articles about orobanchyl acetate and orobanchol, especially those prior to the establishment of their right structures in 2008 and 2011, respectively.

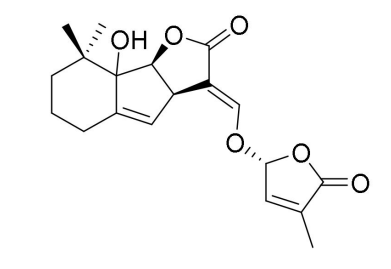

Alectrol, wrong structure previously assigned to orobanchyl acetate

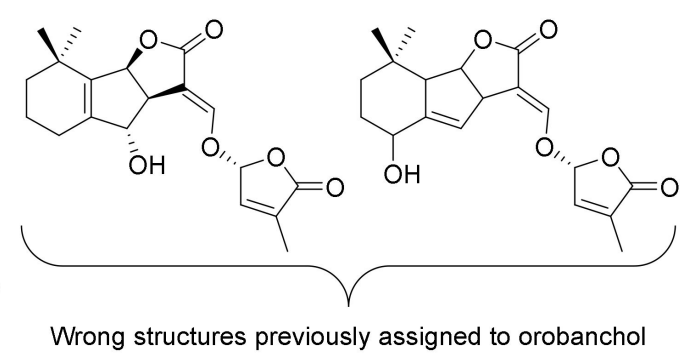

Wrong structures previously assigned to orobanchol

Figure 3. Structure of alectrol, and two wrong structures previously assigned to orobanchol.

After the correction of the structure of orobanchol, SLs also began to be classified according to the stereochemistry of their C-ring, taking the strigol type as $\beta$ orientation and the orobanchol type as $\alpha$ orientation (Figures 1 and 2). It should be noted that this classification criterion is only valid for canonical SLs.

The complexity of characterizing new SLs continues to be a difficulty. An idea of this may be given by the not yet confirmed structures found together with 5-desoxystrigol in tobacco (Nicotiana tabacum), related by their discoverers to methoxy-5-deoxystrigol (Figure 4) $[20,21]$. Yoneyama et al. (2018), on the other hand, related them to the structure of 4-oxomethyl carlactonoate [22]. 

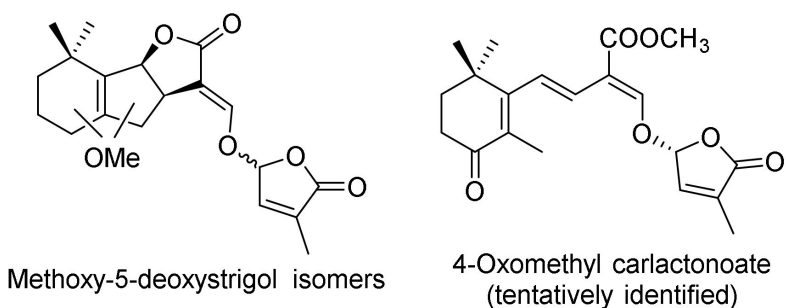

Figure 4. Possible structures of not yet characterized SLs.

Later on, it was found that some SLs present in certain plants are produced by bioconversion of 5-deoxystrigol, such as in the case of the strigol produced by cotton (Gossypium hirstorum) or the sorgomol produced by milkvetch (Astragalus sinicus L.) [23].

SLs with more prominent structural differences were discovered starting in the 2000s: strigone (5-oxo-5-deoxystrigol in old literature), characterized by a ketone at A-ring, was isolated from Houttuynia cordata [24], and solanacol, the first SL found to have an aromatic ring, from tobacco [25], in the same way that solanacyl acetate [21]. Besides, fabacol and fabacyl acetate, SLs with a characteristic epoxide group, were identified in exudates from the Fabaceae family [26]. Fabacol was especially complex to detect due to its low stability and rapid transformation into fabacyl acetate, being also suggested as the epoxidation product of orobanchol [27]. Medicaol, the only SL that has a seven-membered ring such as A-ring and the first didehydro-orobanchol compound isolated, was obtained from Medicago truncatula exudates under phosphate starvation after many years of research [28].

The last canonical SL described in the literature was $7 \beta$-hydroxy-5-deoxystrigol. It was isolated from the Chinese medicinal plant Dokudami (H. cordata) [22]. Two more SLs were identified from this plant; however, due to their small concentrations, their structures are yet to be elucidated.

A key milestone was the discovery of the first non-canonical SL (2012) with the isolation of carlactone [29], which resulted in the current classification method between canonical (Figure 1) and non-canonical (Figure 2) SLs. Two years after the identification of carlactone, carlactonoic acid and methyl carlactonoate were described, and it was found that the latter presented inhibitory activity against Arabidopsis shoot branching. Thus, it was concluded that non-canonical SLs, similarly to canonical ones, have hormonal functions [30]. Therefore, many authors have lately completed a number of research studies to design a valid method to isolate, characterize and handle these poorly stabilized and scarce compounds. Two diastereomers of methyl zealactonoate (also named zealactone) and zeapiranolactone were isolated from corn in 2017 and 2018, respectively [31-33], being the only non-canonical SL to have a lactone such as A-ring. Avenaol was isolated from Avena strigosa along with five other compounds that cannot be elucidated [34]. Heliolactone was isolated from sunflower in 2014, although its complete structure was not confirmed until 2019 [35-37]; and 3-hydroxycarlactone was isolated as an endogenous compound of rice [38]. In 2019, lotuslactone was isolated from the exudates of Lotus japonicus [39], being the only non-canonical SL to have a seven-membered ring such as A-ring. Among canonical SLs, only medicaol has this kind of A-ring, so it can be proposed that lotuslactone and medicaol have a common precursor in planta.

A study in 2020 identified 18-hydroxycarlactonoic acid [40], and suggested that this non-canonical SL is the precursor of lotuslactone. Besides, in another recent study, hydroxymethyl carlactonoate was identified in Arabidopsis as a conversion product of methyl carlactonoate [41]. In this study, eight other hydroxylated carlactone-like SLs were found in Arabidopsis.

\section{Material and Methods}

The bibliography was selected from the database SciFinder by combining the keywords "strigolactones", "isolation of strigolactones", "stimulant germinators", and "ar- 
buscular mycorrhizal fungi growth". After a critical reading of the resulting articles, 105 documents were finally selected and included in this work.

\section{Review on the Identification and Isolation of Strigolactones}

It is important to note that both production and exudation of SLs vary among different plant species, as well as among cultivars or genotypes of the same species [41]. Ćavar et al. [6] generated in 2015 a detailed table that comprised all the data until that date on the identification of SLs in plants. In the present review we extended and updated this table in Table 1, in order to provide all the new discoveries since then, as well as those prior to 2015 that were not included. It should be noted the contribution of the previous reviews by Xie et al. (2016) [27] and Yoneyama et al. (2018) [22] also provide complementary information.

Table 1. Extension and update on the strigolactones identified since the review by Ćavar et al. (2015) [6]. Strigolactones isolated are specified.

\begin{tabular}{|c|c|c|c|}
\hline Strigolactones & Identified in & Isolated & References \\
\hline \multicolumn{4}{|c|}{ Canonical strigolactones } \\
\hline Strigol & Fragaria $x$ ananassa & & [27] \\
\hline \multirow{2}{*}{ Strigyl acetate } & Fragaria $x$ ananassa & & [27] \\
\hline & Sorghum bicolor & & [27] \\
\hline \multirow{2}{*}{ 5-Deoxystrigol } & Fragaria $x$ ananassa & & [27] \\
\hline & Nicotiana tabacum & & {$[21,27]$} \\
\hline \multirow{3}{*}{$4 \alpha$-Hydroxy-5-deoxystrigol } & Nicotiana tabacum & & [21] \\
\hline & Trifolium pretense & $X$ & [42] \\
\hline & Vigna unguiculata & $X$ & [42] \\
\hline $4 \alpha$-Acetoxy-5-deoxystrigol & Nicotiana tabacum & & [21] \\
\hline $7 \beta$-Hydroxy-5 deoxystrigol & Houttuynia cordata & & {$[22]$} \\
\hline \multirow{4}{*}{ Orobanchol } & Cryptomeria japonica & & [22] \\
\hline & Cucumis satious & & [43] \\
\hline & Ginkgo biloba & & [27] \\
\hline & Pinus thunbergii & & [27] \\
\hline \multirow{7}{*}{ Orobanchyl acetate } & Cryptomeria japonica & & [22] \\
\hline & Cucumis satious & & [43] \\
\hline & Ginkgo biloba & & [27] \\
\hline & Nardostachys jatamansi & & [44] \\
\hline & Nicotiana tabacum & & [21] \\
\hline & Oryza sativa & $X$ & [21] \\
\hline & Pinus thunbergii & & [27] \\
\hline \multirow{9}{*}{ 4-Deoxyorobanchol } & Cryptomeria japónica & & [22] \\
\hline & Cucumis sativus & & [43] \\
\hline & Gynkgo biloba & & [27] \\
\hline & Nicotiana tabacum & & [21] \\
\hline & Oryza sativa & & [21] \\
\hline & Pisum sativum & $X$ & {$[27]$} \\
\hline & Populus spp. & $X$ & [27] \\
\hline & Selaginella moellendorfii & & [27] \\
\hline & Solanum lycopersicum & & [27] \\
\hline 7-Oxoorobanchol & Solanum lycopersicum & $X$ & {$[45]$} \\
\hline 7-Oxoorobanchyl acetate & Oryza sativa & & [27] \\
\hline $7 \alpha$-Hydroxyorobanchol & Solanum lycopersicum & & {$[45]$} \\
\hline $7 \beta$-Hydroxyorobanchol & Solanum lycopersicum & & {$[45]$} \\
\hline \multirow{2}{*}{$7 \alpha$-Hydroxyorobanchyl acetate } & Cucumis satious & $X$ & [43] \\
\hline & Solanum lycopersicum & & [45] \\
\hline \multirow{2}{*}{$7 \beta$-Hydroxyorobanchyl acetate } & Cucumis sativus & \multirow{2}{*}{$X$} & [43] \\
\hline & Solanum lycopersicum & & [45] \\
\hline
\end{tabular}


Table 1. Cont.

\begin{tabular}{|c|c|c|c|}
\hline Strigolactones & Identified in & Isolated & References \\
\hline Solanacol & Carthamus tinctorius & & {$[46]$} \\
\hline Medicaol & Medicago truncatula & $X$ & {$[28]$} \\
\hline Fabacol & Pisum sativum & & {$[26,27]$} \\
\hline \multicolumn{4}{|c|}{ Non-canonical strigolactones } \\
\hline Carlactone & $\begin{array}{c}\text { Arabidopsis thaliana } \\
\text { Oryza sativa }\end{array}$ & & $\begin{array}{c}{[7,41]} \\
{[7]}\end{array}$ \\
\hline Carlactonoic acid & $\begin{array}{c}\text { Arabidopsis thaliana } \\
\text { Helianthus annuus } \\
\text { Pinus thunbergii } \\
\text { Populus spp. } \\
\text { Selaginella moellendorffii } \\
\text { Zea Mays }\end{array}$ & & $\begin{array}{l}{[30]} \\
{[27]} \\
{[27]} \\
{[27]} \\
{[27]} \\
{[27]}\end{array}$ \\
\hline Methyl carlactonoate & $\begin{array}{c}\text { Arabidopsis thaliana } \\
\text { Populus spp. }\end{array}$ & & $\begin{array}{l}{[30]} \\
{[27]}\end{array}$ \\
\hline $\begin{array}{l}\text { 3-Hydroxycarlactone } \\
\text { 3-Hydroxycarlactonoic acid } \\
\text { 4-Hydroxycarlactone } \\
\text { 4-Hydroxycarlactonoic acid } \\
\text { Methyl 4-hydroxycarlactonoate } \\
\text { 16-Hydroxycarlactone } \\
\text { 16-Hydroxycarlactonoic acid } \\
\text { Methyl 16-hydroxycarlactonoate }\end{array}$ & Arabidopsis thaliana & & {$[41]$} \\
\hline 18-Hydroxycarlactonoic acid & $\begin{array}{l}\text { Lotus japonicus } \\
\text { Sorghum bicolor }\end{array}$ & & $\begin{array}{l}{[40]} \\
{[47]}\end{array}$ \\
\hline Hydroxymethyl carlactonoate & Arabidopsis thaliana & & [41] \\
\hline Heliolactone & $\begin{array}{c}\text { Helianthus annuus } \\
\text { Zea mays }\end{array}$ & $\begin{array}{l}X \\
X\end{array}$ & $\begin{array}{l}{[35]} \\
{[31]}\end{array}$ \\
\hline $\begin{array}{l}\text { Methyl zealactonoate } \\
\text { (two diastereomers) }\end{array}$ & Zea mays & $x$ & {$[31,32,48]$} \\
\hline Zeapyranolactone & Zea mays & $X$ & [33] \\
\hline Avenaol & Avena strigose & $X$ & {$[34]$} \\
\hline Lotuslactone & Lotus japonicus & $x$ & [39] \\
\hline
\end{tabular}

As stated in Yoneyama et al. (2020) [41], growth conditions and growth stages are also key factors in the production and release of SLs, so it is equally important to check this information when obtaining experimental data from the references.

In order to provide some generalization to the data of sources for the SL isolation, provided in Ćavar et al. [6] and Table 1, it can be highlighted that strigol-type SLs are the only type found in cotton (G. hirsutum), strawberry $(F \times \times$ ananassa), proso millet (Panicum miliaceum) and some medicinal plants ( $H$. cordata or Menispermum dauricum); whereas the orobanchol-type is the sole type found in rice (Oryza sativa), tomato (Solanum lycopersicum), cucumber (Cucumis sativus), ginkgo (Gynko biloba) and Japanese cedar (Criptomeria japonica). Both types have been found in other species, such as pea (Pisum sativum), sorghum (Srghum bicolor), cowpea (Vigna unguiculata and Vigna angularis), milkvetch (Asinicus sinicus), tobacco (N. tabacum), safflower (Carthamus tinctorius), white lupin (Lupinus albus), or garden cosmos (Cosmos bipinnatu), among others.

The case of clover deserves to be highlighted separately, since the species Trifolium pratense (red clover) produces both types of SLs, in contrast to Trifolium incarnatum (crimson clover), for which only orobanchol-type SLs have been found to date.

As a source of non-canonical SLs, with the only exception of Selaginella moellendorffii, for all the producing species (Table 1 ) it has previously been found that they produce some canonical SL (Z. mays or L. japonicus and strigol-type; or Arabidopsis thaliana, Helianthus annuus, Pinus thunbergii or Populus and orobanchol-type). This makes sense 
considering that, as previously detailed Section 1.1, the non-canonical SLs are the precursor of canonical SLs in planta.

Due to the variety of species referred, it was not possible to clearly link specific plant taxonomies with the type of SL they produce.

Focusing attention on the methods to identify and isolate SLs, it should be noted that the identification and isolation of new SLs was made possible by the progressive knowledge on various aspects. Notably, these were the handling conditions of SLs to avoid their degradation, the growth conditions to optimize the SL amounts produced by plants, and specially, the improvements in the techniques of SLs analysis, identification and quantification, mainly mass spectrometry (MS) and nuclear magnetic resonance (NMR). Thus, the isolation of SLs is not the only objective of studies in this field, but also the development of improved methods to identify and quantify SLs in root exudates and extracts. The low amount of SLs in samples and their rapid degradability make the analytical methods fast and have very low limits of quantification, focusing the attention to LC-MS/MS techniques [49]. Another relevant fact is that the methods must consider the matrix effect, for example, by using an internal standard (IS).

In this way, Boutet-Mercey et al. (2018) [50] developed a UHPLC-ESI-MS/MS method, based on deuterium labelled standards, for determining fabacyl acetate (limit of detection $(\mathrm{LOD})=1.25 \mu \mathrm{g} / \mathrm{L}$; limit of quantification $(\mathrm{LOQ})=4.16 \mu \mathrm{g} / \mathrm{L})$, orobanchyl acetate and orobanchol $(\mathrm{LOD}=0.14-0.18 \mu \mathrm{g} / \mathrm{L} ; \mathrm{LOQ}=0.46-0.61 \mu \mathrm{g} / \mathrm{L})$. The method was proved on $1 \mathrm{~g}$ of pea root samples from hydroponic cultures, being qualified by authors as suitable for other complex plant samples. Subsequently, our group published a simple and reliable UHPLC-MS/MS method, developed for the routine analysis of the most common canonical SLs (strigol, solanacol, orobanchol, orobanchyl acetate, 7-oxoorobanchyl acetate, fabacyl acetate, and 5-deoxystrigol), which was applied to exudates and extracts from tomato roots (S. lycopersicum) and using ( \pm )-GR24 (well-known synthetic SL analogue) as IS [51]. The LOQ ranged from $0.05 \mu \mathrm{g} / \mathrm{L}$ (5-deoxystrigol) to $0.96 \mu \mathrm{g} / \mathrm{L}$ (solanacol). The UHPLC-MS/MS method reported by Floková et al. (2020) [52] is also highly sensitive for simultaneous profiling of canonical SLs (strigol, solanacol, orobanchol, sorgomol, sorgolactone, 4-deoxyorobanchol and 5-deoxystrigol) in S. lycopersicum and other vegetal sources (O. sativa, S. bicolor and P. sativum), with LOD values from 0.125 to $2.5 \mathrm{fmol}$. Authors also highlighted the single-step purification required for this method, which uses macroporous polymer-based sorbents. We suggest the review by Halouzka et al. (2020) [53] as a review study specifically focused on the identification and quantification methods of SLs.

\section{Allelopathic Bioactivities of Strigolactones}

SLs are secondary metabolites that act as phytohormones. They play important roles in different aspects of the growth and development of the plant itself, being the regulation of the branching of aerial parts the most studied. A significant number of recent studies on SLs focuses on this issue, such as evaluating the role of SLs production by rootstocks in grafted grapevine plants [54]. Detailed descriptions of endogenous roles of SLs and their mechanisms are available in recent reviews [55,56].

In contrast to those articles that deal with internal roles of SLs, the following sections are focused on the allelopathic effects that SLs generate on neighboring organisms. Particularly, two types of effects are reviewed herein, which are prime examples of allelopathy: the capacity to stimulate the germination of parasitic plants, and the stimulation of AMF hyphae growth. This last allelopathic interaction is a clear illustration of a symbiotic relationship, given between the SL-producing plant for its own benefit, and the AMF, fungi that develop structures around the roots forming arbuscules able to obtain and supply nutrients from the soil to the plant. On the contrary, the case of the parasitic plants is far from being a symbiosis. It consists of an evolutionary mechanism of parasitic plants, whose seeds use the recognition of a specific compound released by a potential host as a key requirement to germinate. Thus, by this recognition, the parasitic plant would assure its proximity to a proper host plant, being the only beneficiary of this allelopathic process. 
It should be noted that these exogenous uses of SLs and their analogues are among the most studied, though other promising uses (such as phytotoxic herbicides, anticancer drugs, etc.) are currently being studied [57,58]. In this regard, SLs also accelerate the leaf senescence and trigger cell death in darkness, as proved in bamboo (Bambusa oldhamii) [59], perennial ryegrass (Lolium perenne) [60] or rice [61], although it should be noted that the SL tested in studies such as these were the synthetic analogue GR24.

\subsection{Germination Activity on Parasitic Plant Seeds, and Structure-Activity Relationships}

Seeds germinate under the right temperature, humidity, oxygen, and light conditions. Seeds of parasitic plants, in addition, will not germinate unless they are stimulated by certain specific compounds, found in soils to ensure that there is a host nearby. Thus, the study of parasitic weeds has attracted the attention of allelopathy research, being found that SLs produced by plants are germination stimulators of certain parasitic species. Especially, the species from the genera Striga (commonly known as witchweed), Orobanche and Phelipanche (commonly known as broomrape), all of them from the family Orobanchaceae. These weeds affect important crops for human consumption worldwide, such as sunflower, legumes, cereals, or tomato, with possible devastating effects [62,63].

The stimulatory activity of SLs has been widely studied through bioassays, which generally consist in the in vitro reproduction of the conditions that a parasitic plant seed requires to germinate. After the addition of the testing compound and the incubation of samples for some days, the parameter to measure is the percentage of germinated seeds, calculated by direct counting from photographs of the samples (Figure 5) [64,65]. A new method for germination assays was reported, which uses the absorbance analysis to obtain the values of germination percentages without the need for counting [66]. All these bioassays can be performed with different purposes: moving forwards in the purification and isolation of new germination stimulators, checking the effectiveness of SLs, or determining the specificity of SLs with different parasitic species.
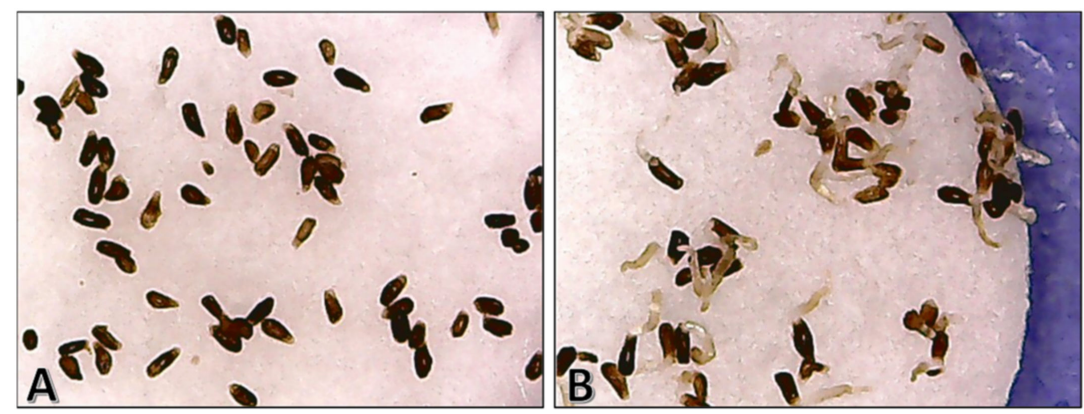

Figure 5. Photographs of Orobanche cumana seeds after a germination bioassay. (A) No germinated seeds, after treatment with an inactive compound; (B) almost all germinated seeds after treatment with a high-active compound.

Ćavar et al. [6] generated the first table that comprised most of the reported germination activity results showed by SLs assayed until 2015, together with the values of the maximum activity level achieved (percentage of germinated seeds). This previous review was very significant, since it gathers information that is exhaustive to obtain. Herein, Table 2 extends and updates this review, providing all the new discoveries since 2015, as well as those prior that were not included. Among them, peagol (structure shown in Table 2), canonical SL-like compound isolated by Evidente et al. (2009) from pea root exudates [67], was included, since its structure is closely related to orobanchol-type SLs. 
Table 2. Extension and update on the maximum germination stimulation activity data described for strigolactones since the review by Ćavar et al. (2015) [6].

\begin{tabular}{|c|c|c|}
\hline Strigolactones & Parasitic Plant Species (Activity and Concentration) & References \\
\hline \multicolumn{3}{|c|}{ Canonical strigolactones } \\
\hline \multirow{9}{*}{ Strigol } & Alectra vogelii $(50 \% 100 \mathrm{nM})$ & [13] \\
\hline & Orobanche cumana (19\% $100 \mathrm{nM})$ & [68] \\
\hline & Orobanche minor $(92 \% 0.1 \mathrm{nM} ; 83 \% 1 \mathrm{nM}$ for $( \pm)$ strigol $)$ & {$[18,25]$} \\
\hline & Phelipanche aegyptiaca (50\% 100 pM) & {$[13]$} \\
\hline & Phelipanche ramosa $(80 \% 0.1 \mathrm{nM} ; 85 \% 10 \mathrm{nM}$ for $( \pm)$ strigol $)$ & {$[18,25]$} \\
\hline & Striga asiatica $(50 \% 100 \mathrm{pM})$ & {$[13]$} \\
\hline & Striga gesnerioides $(0 \% 10 \mathrm{nM}$ or $1 \mu \mathrm{M})$ & [69] \\
\hline & Striga hermonthica $(70 \% 1 \mu \mathrm{M})$ & [69] \\
\hline & Striga lutea $(50 \% 10 \mathrm{pM})$ & {$[70]$} \\
\hline Strigyl acetate & Phelipanche ramosa $(70 \% 1 \mathrm{nM})$ & [18] \\
\hline \multirow{5}{*}{ 5-Deoxystrigol } & Orobanche minor (87\% $1 \mathrm{nM}$ for $( \pm)$ 5-deoxystrigol) & [71] \\
\hline & Orobanche crenata ( $45 \% 10 \mu \mathrm{M}$ for $( \pm)$ 5-deoxystrigol) & [72] \\
\hline & Striga gesnerioides $(0 \% 10 \mathrm{nM}$ or $1 \mu \mathrm{M})$ & [69] \\
\hline & Striga hermonthica $(75 \% 1 \mu \mathrm{M}$ & [69] \\
\hline & $80 \% 0.1 \mu \mathrm{M}$ for $( \pm)$ 5-deoxystrigol) & [72] \\
\hline \multirow{6}{*}{ Sorgolactone } & Alectra vogelii $(50 \% 1 \mu \mathrm{M})$ & [13] \\
\hline & Orobanche minor (92\% $10 \mathrm{nM}$ for $( \pm)$ sorgolactone) & [71] \\
\hline & Phelipanche aegyptiaca (50\% $100 \mathrm{nM})$ & [13] \\
\hline & Striga asiatica $(50 \% 10 \mathrm{pM})$ & [13] \\
\hline & Striga gesnerioides $(0 \% 10 \mathrm{nM}$ or $1 \mu \mathrm{M})$ & [69] \\
\hline & Striga hermonthica $(55 \% 1 \mu \mathrm{M})$ & [69] \\
\hline \multirow{3}{*}{ Sorgomol } & Orobanche minor (93\% $10 \mathrm{nM})$ & [71] \\
\hline & Striga gesnerioides $(0 \% 10 \mathrm{nM}$ or $1 \mu \mathrm{M})$ & [69] \\
\hline & Striga hermonthica $(75 \% 1 \mu \mathrm{M})$ & [69] \\
\hline \multirow{3}{*}{ Orobanchol } & Orobanche cumana $(64 \% 100 \mathrm{nM})$ & [68] \\
\hline & Striga gesnerioides $(50 \% 1 \mathrm{nM})$ & [42] \\
\hline & Striga hermonthica $(15 \% 10 \mu \mathrm{M})$ & [73] \\
\hline \multirow{3}{*}{ Orobanchyl acetate } & Orobanche minor (95\% $100 \mathrm{pM})$ & [71] \\
\hline & Striga gesnerioides ( $40 \% 0.1 \mathrm{nM} ; 69 \% 350 \mathrm{nM})$ & {$[42,74]$} \\
\hline & Striga hermonthica $(35 \% 10 \mu \mathrm{M})$ & [73] \\
\hline \multirow{2}{*}{ 7-Oxoorobanchol } & Orobanche minor (83\% $10 \mathrm{nM})$ & [71] \\
\hline & Phelipanche ramosa ( $85 \% 10 \mathrm{nM})$ & {$[75]$} \\
\hline \multirow{2}{*}{ 7-Oxoorobanchyl acetate } & Orobanche cumana (94\% $100 \mathrm{nM})$ & [68] \\
\hline & Orobanche minor $(95 \% 1 \mathrm{nM})$ & [75] \\
\hline \multirow{2}{*}{$7 \alpha$-Hydroxyorobanchyl acetate } & Orobanche minor (90\% $1 \mathrm{nM})$ & \multirow{2}{*}{ [43] } \\
\hline & Phelipanche ramosa ( $85 \% 10 \mathrm{nM})$ & \\
\hline \multirow{2}{*}{$7 \beta$-Hydroxyorobanchyl acetate } & Orobanche minor $(90 \% 0.1 \mathrm{nM})$ & \multirow{2}{*}{ [43] } \\
\hline & Phelipanche ramosa ( $85 \% 10 \mathrm{nM})$ & \\
\hline \multirow{2}{*}{ Solanacol } & Orobanche minor (97\% $100 \mathrm{pM})$ & [71] \\
\hline & Phelipanche ramosa $(83 \% 0.1 \mathrm{nM})$ & [25] \\
\hline Fabacyl acetate & Orobanche minor ( $88 \% 1 \mathrm{nM})$ & [71] \\
\hline \multirow{2}{*}{ Equimolar mixture of orobanchol and strigol } & Orobanche cumana (24\% $100 \mathrm{nM})$ & \multirow{2}{*}[68]{} \\
\hline & Orobanche minor (91\% $100 \mathrm{nM})$ & \\
\hline \multirow{2}{*}{$\begin{array}{l}\text { Equimolar mixture of orobanchol and } \\
\text { 7-oxoorobanchyl acetate }\end{array}$} & Orobanche cumana (0\% $100 \mathrm{nM})$ & \multirow{2}{*}{ [68] } \\
\hline & Orobanche minor ( $80 \% 100 \mathrm{nM})$ & \\
\hline
\end{tabular}


Table 2. Cont.

\begin{tabular}{|c|c|c|}
\hline Strigolactones & Parasitic Plant Species (Activity and Concentration) & References \\
\hline Peagol * & $\begin{array}{l}\text { Orobanche crenata }(7 \% 10 \mu \mathrm{M}) \\
\text { Orobanche foetida }(27 \% 10 \mu \mathrm{M}) \\
\text { Orobanche minor }(3 \% 10 \mu \mathrm{M}) \\
\text { Phelipanche aegyptiaca }(42 \% 10 \mu \mathrm{M})\end{array}$ & [67] \\
\hline \multicolumn{3}{|c|}{ Non-canonical strigolactones } \\
\hline Carlactone & Striga hermonthica $(62 \% 330 \mu \mathrm{M})$ & [29] \\
\hline Methyl carlactanoate & Orobanche cumana ( $80 \% 30 \mathrm{nM}$ of racemate) & [76] \\
\hline Heliolactone & $\begin{array}{l}\text { Orobanche crenata }(80 \% 1000 \mathrm{nM}) \\
\text { Orobanche cumana }(88 \% 30 \mathrm{nM} ; 91 \% \text { for racemate) } \\
\text { Orobanche minor }(80 \% 1 \mathrm{nM}) \\
\text { Phelipanche aegyptiaca }(30 \% 1000 \mathrm{nM}) \\
\text { Striga hermonthica }(80 \% 1000 \mathrm{nM})\end{array}$ & $\begin{array}{l}{[35]} \\
{[76]} \\
{[35]} \\
{[35]} \\
{[35]}\end{array}$ \\
\hline Methyl zealactonoate & $\begin{array}{l}\text { Orobanche minor }(80 \% 100 \mathrm{nM}) \\
\text { Phelipanche ramosa }(85 \% 10 \mathrm{nM}) \\
\text { Striga hermonthica }(85 \% 100 \mathrm{nM})\end{array}$ & [32] \\
\hline $\begin{array}{l}\text { Methyl zealactonoate 1aMethyl } \\
\text { zealactonoate } 1 \mathrm{~b}\end{array}$ & $\begin{array}{l}\text { Striga hermonthica }(60 \% 30 \mu \mathrm{M}) \\
\text { Striga hermonthica }(50 \% 3 \mu \mathrm{M})\end{array}$ & [31] \\
\hline Avenaol & $\begin{array}{l}\text { Orobanche minor (55\% } 1000 \mathrm{nM}) \\
\text { Phelipanche ramosa }(90 \% 100 \mathrm{nM}) \\
\text { Striga hermonthica }(50 \% 1000 \mathrm{nM})\end{array}$ & [34] \\
\hline Lotuslactone & $\begin{array}{l}\text { Orobanche minor }(90 \% 1 \mathrm{nM}) \\
\text { Phelipanche ramosa }(55 \% 0.1 \mathrm{nM}) \\
\text { Striga hermonthica }(80 \% 10 \mathrm{nM})\end{array}$ & [39] \\
\hline
\end{tabular}

* Structure not included in Figure 1 for not sharing all the characteristics of canonical strigolactones.

Striga hermonthica, Phelipanche ramosa, and Orobanche minor were tested for a wider variety of SLs. Thus, in order to provide an easy comparison of the activity levels for these species, we created the graphs shown in Figure 6. It should be noted that units of concentration expressed in Figure 6 were homogenized for each graph, in order to clearly emphasize which SLs are highly active at lower concentrations.

Among all the SLs, strigone can be considered an example of efficient agrochemical, since its treatment at low concentration $\left(10^{-5} \mu \mathrm{M}\right)$ can achieve the $100 \%$ of S. hermonthica germination [24]. Activity of solanacol and orobanchyl acetate may also be highlighted, since percentages over $95 \%$ were obtained for $O$. minor at $0.1 \mathrm{nM}$ [71]. Both SLs also achieved around $80 \%$ for $P$. ramosa at 0.1 and $1 \mathrm{nM}$, respectively [25].

Different SLs have also been tested on Striga gesnerioides, where medium levels for orobanchyl acetate (69\% at $350 \mathrm{nM}$ [74]) and orobanchol (50\% at $1 \mathrm{nM}$ [42]) were found. However, null activity was obtained for strigol, 5-deoxystrigol, sorgolactone, and sorgomol at concentrations as high as $100 \mathrm{nM}$ [69]. These results denote certain specificity of S. gesnerioides for the kind of SL that achieve its germination, specifically in favor of orobanchol-type SLs. This conclusion can rely on the structure-activity relationship study published by Nomura et al. (2013) [69], carried out with a wide variety of SLs and their stereoisomers, obtained by synthesis.

Thus, from a structural point of view, the configuration of a particular SL is normally decisive when it comes to its germination activity on parasitic plants. The case previously mentioned for the preference of S. gesnerioides for orobanchol-type SLs is further accentuated for S. hermonthica and the strigol-type SLs: orobanchyl acetate was the only orobanchol-type SL found active (45\%) [73], whereas for strigol-type or non-canonical SLs can achieve more than $80 \%$ (Figure 6). 


\section{Striga hermonthica}

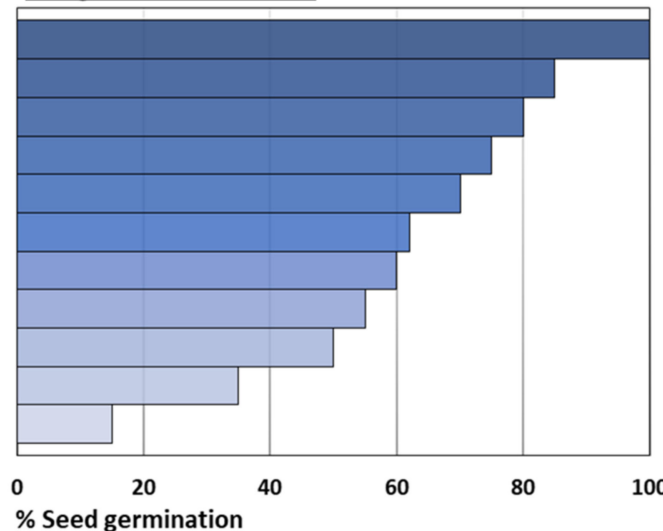

$\square$ Strigone $\left(10^{-5} \mu \mathrm{M}\right)$

$\square$ Methyl zealactanoate $(0.1 \mu \mathrm{M})$

$\square$ Lotuslactone $(0.01 \mu \mathrm{M}),( \pm)$ 5-deoxystrigol $(0.1 \mu \mathrm{M})$ and heliolactone $(1 \mu \mathrm{M})$

$\square$ Sorgomol or 5-deoxystrigol (1 $\mu \mathrm{M})$

$\square$ Strigol $(1 \mu \mathrm{M})$

$\square$ Carlactone $(330 \mu \mathrm{M})$

$\square$ Methyl zealactanoate 1a (30 $\mu \mathrm{M})$

$\square$ Sorgolactone $(1 \mu \mathrm{M})$

$\square$ Avenaol $(1 \mu \mathrm{M})$ and methyl zealactanoate $1 \mathrm{~b}(3 \mu \mathrm{M})$

$\square$ Orobanchyl acetate $(10 \mu \mathrm{M})$

$\square$ Orobanchol $(10 \mu \mathrm{M})$

\section{Phelipanche ramosa}

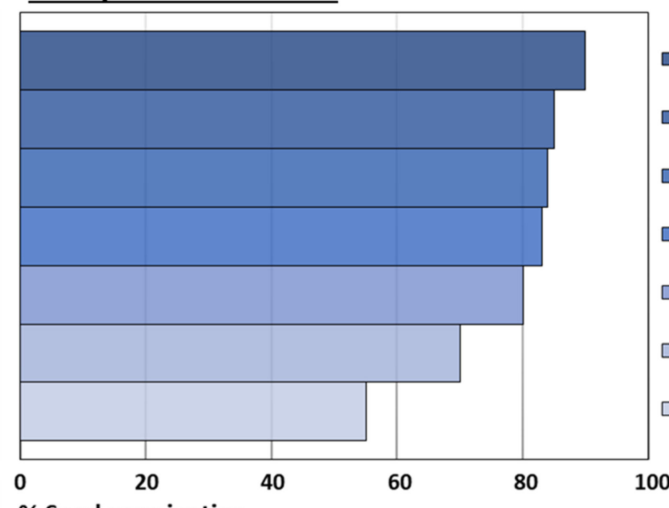

- Strigone (1 $\mathrm{nM})$ and avenaol (100 nM)

( \pm ) Strigol, 7-oxoorobanchol, methyl zealactanoate,

$7 \alpha$ - or $7 \beta$-hydroxyorobanchyl acetate (10 nM)

- Orobanchol (1 nM)

Solanacol (0.1 nM)

Strigol (0.1 nM), 7-oxoorobanchyl acetate

or orobanchyl acetate (1 $\mathrm{nM}$ )

Strigyl acetate (1 nM)

$\square$ Lotuslactone (0.1 nM)

$\%$ Seed germination

\section{Orobanche minor}

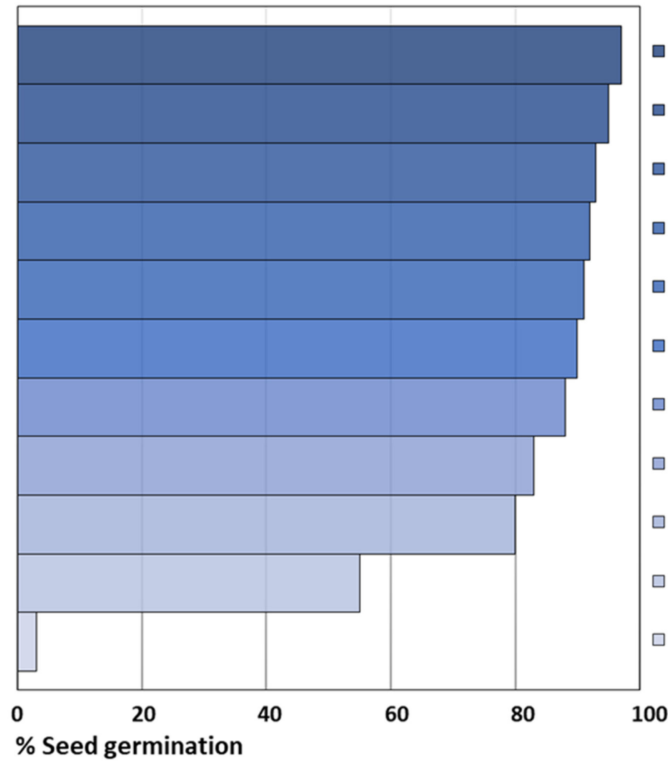

Solanacol (0.1 nM)

Orobanchyl acetate $(0.1 \mathrm{nM})$

Sorgomol (10 $\mathrm{nM})$

Strigol $(0.1 \mathrm{nM})$ and $( \pm)$ sorgolactone $(10 \mathrm{nM})$

Orobanchol (0.1 nM)

$7 \beta$-Hydroxyorobanchyl acetate (0.1 nM), $7 \alpha$-hydroxyorobanchyl acetate,

strigyl acetate or lotuslactone (1 $\mathrm{nM})$ and strigone (100 $\mathrm{nM})$

Fabacyl acetate (1 nM) and ( \pm ) 5-deoxystrigol (10 nM)

( \pm ) Strigol (1 $\mathrm{nM}$ ) and 7-oxoorobanchol (10 nM)

Heliolactone (1 $\mathrm{nM})$, 7-oxoorobanchyl acetate (10 nM)

and methyl zealactanoate $(100 \mathrm{nM})$

Avenaol (1000 nM)

Peagol (10,000 nM)

Figure 6. Stimulatory activity levels of the strigolactones tested on Striga hermonthica, Phelipanche ramosa, or Orobanche minor seeds germination, in descending order of activity.

In addition, it is worth highlighting the activity of $45 \%$ achieved by $( \pm)$-deoxystrigol [72] and, specially, the value of $80 \%$ achieved by the $1000 \mathrm{nM}$ application of heliolactone on the seeds of Orobanche crenata [35]. This is because this parasitic weed species is very selective for the type of compound that elicits its germination, based on the results also obtained in our research group. As an example, we synthetized and evaluated the activity 
of nine eudesmanestrigolactones, canonical analogues of SLs highly active on P. ramosa and O. cumana, whose activity on $O$. crenata did not exceed the 53\% [57]. In addition, we only obtained significant activity levels with $O$. crenata for a few other compounds. This was the case of the natural products anhydrojudaicin or santamarine, with $15 \%$ seed germination at 1 or $0.1 \mu \mathrm{M}[64]$.

The orientation of the acetate group in the hydroxyorobanchyl acetates also proved to have some relevance for the activity levels achieved at the lowest concentrations, since $7 \beta$-hydroxyorobanchyl acetate improved the activity of its isomer $7 \alpha$-hydroxyorobanchyl acetate for O. minor (0.01-0.1 nM) and P. ramosa (0.01-1 nM) germination [43].

Other relevant points to discover of the germinating activity of SLs are their possible synergetic or antagonistic effects, when two or more are simultaneously applied. Currently there are not many studies on it, being worth highlighting the unpublished results of Fernández-Aparicio's group in a germination assay testing equimolar mixtures of some SLs, showed in a recent review by Yoneyama [68]. For the germination of O. minor, germination percentages of mixtures of orobanchol and strigol or 7-oxoorobanchyl acetate were in the same range of those obtained by the single SLs (80-93\%, at $100 \mathrm{nM})$. The case of O. cumana differed, showing how strigol antagonizes orobanchol to some extent, and especially, how the activity for the mixture of orobanchol and 7-oxoorobanchyl acetate is null, being the activity of these SLs of $64 \%$ and $94 \%$, respectively, when tested individually. Therefore, the study of the effects of combined SLs can be interesting for obtaining possible synergetic mixtures, as well as other antagonistic mixtures.

The activity showed by some SLs on O. cumana, damaging parasitic weed for sunflower, may also be noted, since no positive results were published before 2019 (though they had been obtained for different synthetic analogues or mimics). Particularly, racemates of the non-canonical heliolactone, or methyl carlactanoate, showed high activity levels (80-91\%), which is relevant to the $88 \%$ value achieved by pure heliolactone [76]. Among the canonical SLs, results were only found for strigol and orobanchol, with lower percentages (19\% and 64\% respectively) [68] and denoting a possible preference of O. cumana for the non-canonical SLs. However, the aforementioned canonical SLs analogues named eudesmanestrigolactones generate percentages of $80-100 \%$ in the range $0.1-100 \mu \mathrm{M}$, as well as the well-known synthetic analogue GR24 [57]. Other examples of active canonical analogues have been published $[77,78]$, so deeper studies should be carried out to obtain more substantiated conclusions on possible structural advantages for the germination of O. cumana in regard to canonical/non-canonical structures.

Yoshimura et al. (2019) [76], in addition to heliolactone, tested the synthetic diastereomers at C-6 and C-11 of this non-canonical SL on O. cumana, at a concentration of $30 \mathrm{nM}$. In comparison with the maximum result achieved by heliolactone $(88 \%)$, it was obtained a percentage slightly smaller for the $(6 R)$-isomer $(76 \%)$, whereas the value for the (11S)-isomer decreased to $61 \%$. These results showed how the own isomeric features of non-canonical SL should also be considered to achieve optimal activities, as well as how heliolactone and its diastereomers possess promising potential for the control of O. cumana in terms of activity.

\subsection{Growth Stimulatory Activity on Arbuscular Mycorrhizal Fungi Hyphae}

Arbuscular mycorrhizal fungi (AMF) are a class of beneficial microorganisms widely distributed in soils, forming symbiotic associations with land plants (70-80\% of species) for more than 460 million years [2,55]. In this symbiotic interaction, AMF supplies water and nutrients from the soil (beyond the root rhizosphere) to the host plant; and the host provides photoassimilates (carbohydrates produced by photosynthesis in the leaves [79]) to the AMF [80]. In this context, SLs are well-known allelochemicals that stimulate the growth of AMF. However, much remains to be discovered, being the study of the hormonal biosynthesis and perception pathways in AMF proper points [2].

This symbiosis is related to the obtaining of inorganic phosphate $(\mathrm{Pi})$, one of the most important nutrients. Under Pi starvation, the expression of genes involved in SL 
biosynthesis and transport are induced, which would inhibit axillary bud outgrowth and promote leaf senescence to prepare the plant for the nutrient scarcity [55]. A recent study in tomato showed that SLs are not just the end products of the phosphate starvation response, being concluded an additional major role in the regulation of this response process as phytohormones [81]. The current knowledge on the molecular mechanism of SLs transport covers mostly the Solanaceae family, so the study of Banasiak et al. (2020) [82] might be mentioned as it is focused on the family Fabaceae, whose root anatomy differs from most angiosperms in the lack of exodermis. In the model legume $M$. truncatula, it was identified and characterized an ATP-binding cassette membrane transporter (MtABCG59) involved in SL transport from the site of biosynthesis to the soil, promoting the association of the plant with AMF. Other recent studies showed some effects of cultivating Striga-resistant (orobanchol-producing) and Striga-susceptible (5-deoxystrigol-producing) sorghum cultivars, in different conditions of AMF inoculation and P fertilization [83].

In addition to Pi starvation, the production of SLs is also promoted by other types of stress, such as elevated atmospheric carbon dioxide concentrations [84], or N-deficiency [48], being both effects studied in recent articles in tomato and maize roots, respectively.

Salt stress and drought are also influencing, as reviewed in López-Ráez (2016) [85]. In the case of salt stress, the SL production can gradually increase with treatment time of $\mathrm{NaCl}$, and the AMF symbiosis can alleviate this stress by altering SL levels in the host, and supplying up to $20 \%$ of water uptake $[86,87]$. Besides, studies performed in rice suggest that SL biosynthesis and signaling play a key role in determining the rhizomicrobiome, which may assist in the stress resilience of the host plant [88]. The symbiosis between rice and AMF was recently reviewed by Mitra et al. (2021) [89].

Once roots exudate SLs, they are able to act as allelochemicals to AMF, increasing hyphal branching significantly after the chemical recognition. Although the spores of AMF can germinate and grow to some extent in the absence of a host, their growth is rather limited, and they will not be able to complete their full life cycle unless they find a host. Thus, their spores normally germinate only when certain chemical signals from their host plant are detected [14]. SLs can be one of such chemical signals, but not all the SLs are equally effective to this purpose. In order to determine a particular SL activity, a bioassay is carried out in which mycorrhizal fungi spores are placed onto Petri dishes under optimal growth conditions. Then, each specific SL to be investigated is added at increasing concentrations in order to determine its minimum effective concentration (MEC), following the method of Akiyama et al. [90]. Ćavar et al. [6] generated a table including the data on the SLs' growth-stimulatory activity on AMF to 2015. Table 3 extends and updates such data.

Table 3. Growth-stimulatory activity on arbuscular mycorrhizal fungi hyphae by the new strigolactones described since 2015 [6].

\begin{tabular}{ccc}
\hline Strigolactone & AMF Species and MEC Values & References \\
\hline Medicaol & Gigaspora margarita $(10 \mathrm{pg} /$ disc $)$ & {$[28]$} \\
\hline 4-Deoxyorobanchol & Gigaspora margarita $(3 \mathrm{pg} / \mathrm{disc})$ & {$[28]$} \\
\hline$( \pm)$ Strigone & Gigaspora margarita $(10 \mathrm{pg} / \mathrm{disc})$ & {$[90]$} \\
\hline Carlactone (racemate) & Gigaspora margarita $(100,000 \mathrm{pg} / \mathrm{disc})$ & {$[91]$} \\
\hline Methyl carlactonoate (racemate) & Gigaspora margarita $(1000 \mathrm{pg} / \mathrm{disc})$ & {$[91]$} \\
\hline Carlactonoic acid (racemate) & Gigaspora margarita $(100 \mathrm{pg} / \mathrm{disc})$ & {$[39]$} \\
\hline Methyl zealactonoate & Gigaspora margarita $(10,000 \mathrm{pg} / \mathrm{disc})$ & {$[39]$} \\
\hline Avenaol & Gigaspora margarita $(1,000,000 \mathrm{pg} / \mathrm{disc})$ & {$[39]$} \\
\hline Heliolactone & Gigaspora margarita $(10,000 \mathrm{pg} / \mathrm{disc})$ & {$[39]$} \\
\hline Lotuslactone & Gigaspora margarita $(1000 \mathrm{pg} / \mathrm{disc})$ & \\
\hline
\end{tabular}

pg/disc: picograms of tested compound by disc.

Comparing the MEC values showed at Table 3, with those provided in the review by Ćavar et al. (2015) [6], the most active compounds for Gigaspora margarita are orobanchol 
(1 pg/disc), followed by 4-deoxyorobanchol and 5-deoxystrigol (3 pg/disc), and fabacyl acetate, 7-oxoorobanchyl acetate, orobanchyl acetate, and medicaol (10 pg/disc). Strigone (named as 5-oxo-5-deoxystrigol in the original reference [90]) was not included in this list, since the MEC value showed in Table 3 (10 pg/disc) was not achieved by the enantiomerically pure compound. Besides, medicaol was tested together with the synthetic 4-deoxymedicaol and all its diastereomers. One of them proved to be active in the same way, and the others improved the activity level (MEC $=1 \mathrm{pg} /$ disc) [28].

In the study of Mori et al. (2016) [91] two synthetic analogues structurally related to dimers of non-canonical SLs were also shown (Figure 7), and whose MEC values were $10 \mathrm{pg} /$ disc. Other related compounds were presented in the same study, with MEC values of 100 or $1000 \mathrm{pg} /$ disc, as well as three hydroxylated carlactone derivatives with much higher MEC values $(10,000-1,000,000 \mathrm{pg} /$ disc $)$.
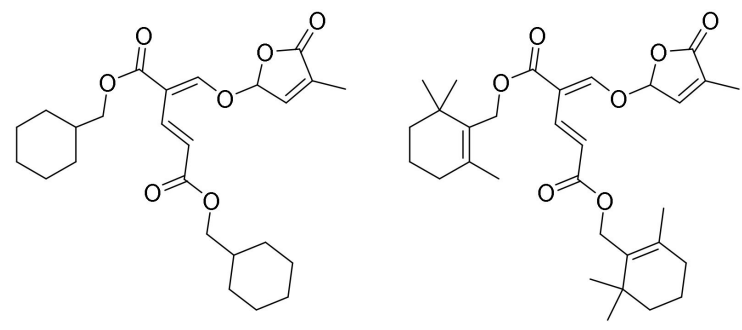

Figure 7. High active analogues of non-canonical strigolactones on Gigaspora margarita.

Most of the studies have focused on Gigaspora species (just another genus, Glomus, has been found to be tested in SL studies [6]). Gigaspora rosea is another example, and for which it is worth noting that sorgolactone showed an outstanding value of $1.31 \times 10^{-15} \mathrm{M}$ [92]. Therefore, the search for any correlation between the type of SL structure and the specific mycorrhizal fungi that they activate is an interesting aspect still to be explored. For this purpose, it would be of great interest to carry out further studies on the activity shown by the different SLs on a wider range of mycorrhizal fungi species.

\subsection{Applications of Strigolactones in Agriculture}

SLs can be used to control parasitic plant plagues thanks to their capacity to stimulate the germination of the seeds of these plants. They can, therefore, be used in trap crops or suicidal germination strategies for preventing the infestations of parasitic weeds. The fact that some SLs require low concentrations to induce the germination of high percentages of seeds, makes these compounds especially promising agrochemicals, combining effectiveness and minimal environmental impact. On the other hand, their ability to stimulate AMF would be beneficial for crops by increasing the colonization of these symbiotic microorganisms in roots. For agriculture, this can lead to avoiding or minimizing the use of fertilizers, being AMF biofertilizers that represent an environmentally friendly alternative that additionally can increase the crop resilience against diverse types of stress [93].

Trap crops do not intend to achieve the direct control of parasitic plants, but rather a reduction in the infestation levels over time by reducing the soil seed banks. Trap crops are fake hosts that exude SLs into the soil and cause the germination of the parasitic plants seeds. In a trap crop strategy, crops are harvested before the parasitic plant flowering occurs so that its life cycle is interrupted and its reproduction is prevented [94]. This technique has been widely applied, especially against $O$. crenata or P. aegyptica [95]. Soybeans, for instance, have been used as a trap crop before planting sunflowers; whereas oat, fenugreek and clover have been used to reduce the level of $O$. crenata infestation before planting beans or peas [63]. Other examples of crops that have shown an interesting potential as trap crops include white mustard or lentil [96].

Alternatively to the sowing of trap crops, certain compounds with proven germination activity can be applied directly to the infested soil to trigger the germination of the parasitic seeds. This strategy is known as suicidal germination or the honeypot strategy [57]. When 
the parasitic seeds germinate in the absence of a host, they can hardly survive for more than just a few days, since, in the absence of a host plant, they cannot obtain the nutrients that they require for their full development [63]. Some SLs exuded by host plants are known for their ability to induce the germination of parasitic plants in certain ecosystems. This particular family of natural compounds is among the most studied in this field.

The mechanisms by which SLs induce the germination of parasitic plants are complex, and their details are not yet fully known. They were recently reviewed by Nelson (2021) [97], and the review by Zwanenburg et al. (2016) is equally recommended [98]. In brief, the mechanisms would be initiated by the activation of the KAI2d proteins by the SLs, as it was suggested by in vitro, in vivo, and in silico studies. This process would occur due to the hydrolysis (via addition-elimination reaction) of the enol ether bond of the SLs, and later attachment of the released D-ring (hydroxylated methyl furanone) to the histidine residue of the KAI2d proteins [97]. Conformational changes in the receptor pocket are induced as consequence, which trigger a cascade of reactions in the signal transduction [98]. However, different relevant questions are still to be answered, including how bioactive noncanonical SLs are perceived by the parasitic seeds. Other relevant questions are in regard to the specificity of the SL receptors, and how KAI2d proteins would adapt facultative hemiparasites that do not show host-activated germination [97,99].

It is also worth highlighting other strategies for the control of parasitic weeds, which can be combined with trap crops or the suicidal germination in integrated pest management strategies. Specifically, it can be suggested the cultivation of SL-producing plants, which exudate different SLs whose effect on parasitic seeds is antagonistic, together with crops. The objective of this intercropping strategy would not be to stimulate germination of parasitic weeds, but to hinder it. The results of Fernández-Aparicio's group [68], previously described in Section 4.1, can provide an example of the possibilities of this strategy: cultivating producer plants of orobanchol and 7-oxoorobanchyl acetate, together with the crop that can be damaged by O. cumana, for example sunflower. It should also be considered that the SLs (or in general, the active compounds) can be supplied externally, thus avoiding the cultivation of the SL-producing plants and ensuring the required concentration of the treatment. If the active compound is supplied in formulations that improve its properties (such as solubility and stability, by encapsulation or using specific solvents), the effectiveness can notably increase. However, it should be noted the complexity of the biotic and abiotic factors that intervene in contexts such as this, serve as an example the insufficient control of $S$. hermonthica observed after intercropping maize with different legume species [100].

The treatment of crops with inhibitory compounds of the SL biosynthesis, which inhibit the production of SLs in the host plants, can provide an alternative tool. The result would be similar to that of intercropping: the parasitic seeds do not have the compounds that elicit their germination. In this respect, azole-type compounds have been studied, since they inhibit the oxidation of carlactone into canonical SLs (see Scheme 1). Particularly, the compound TIS108 (Figure 8) proved to reduce the production of SLs in both rice and tomato with no adverse effects on tillering or shoot branching, and, moreover, it reduced parasitism of O. minor and S. hermonthica (greenhouse pot test) [101]. This compound inhibited the formation of 4-deoxyorobanchol in rice in a dose-dependent manner in the range of 10-100 nM [102]. TIS108 can be likewise interesting in the suicidal germination context, since it stimulates rapidly the germination of high percentages of Phelipanche aegyptiaca seeds if the preconditioning period in water (common in germination bioassays) is not applied to the seeds [103]. On the other hand, compounds able to inhibit the SL receptors in weed seeds can be equally useful to control the parasitic pests. As an example, compound RG4 (also called soporidine, Figure 8) inhibits S. hermonthica germination at concentrations that are not phytotoxic to rice [104]. 


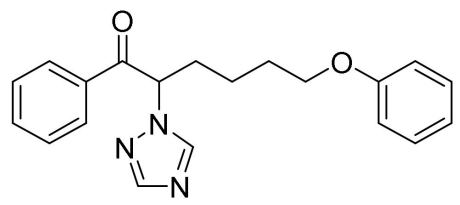

TIS108

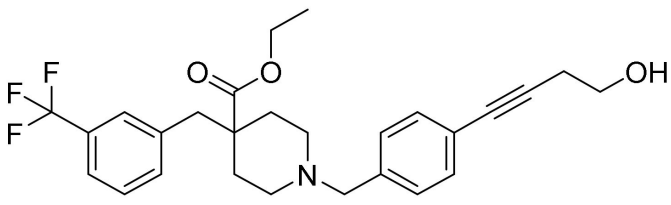

Soporidine, also known as RG4

Figure 8. Examples of strigolactone inhibitors.

Strategies such as the aforementioned, based on reducing SL exudation or production, have promising potential for species such as faba bean and rice. However, impact issues would limit their use for maize or tomato crops, and it is suggested that modifying the SL composition is a better alternative [105].

In addition to all the advantages that the use of SL can provide to agriculture, other negative aspects must be considered regarding interactions with other organisms. We highlight the disadvantages indicated in the review by López-Ráez et al. (2017) [93], related to an increased susceptibility to pathogenic damage of bacteria, fungi and oomycetes, such as leafy gall syndrome (by Rhodococcus fascians), stomatal closure (Pectobacterium carotovorum and Pseudomonas syringae), or reducing the levels of the defense hormones against Alternaria alternata and Botrytis cinerea, when the host plant is SL-deficient.

\section{Conclusions}

Numerous research works have focused on SLs, either to present newly identified structures or to report on new activities exhibited by these compounds that can be useful in farming processes. In addition to inducing the germination of root parasitic plants seeds, SLs have been confirmed to act as plant hormones that regulate shoot branching, and play important roles as allelochemicals regarding the symbioses between higher plants and the arbuscular mycorrhizal fungi.

This review presented a global overview on the identification and isolation of the 41 SLs listed up to date, as well as their main allelopathic bioactivities (germination activity and hyphal branching). From 2012, attention in this area and further progress have been conferred in part on non-canonical SLs. This provided a greater variety to the SLs family, allowing the conclusion of some structure-activity relationships, such as the preference of S. gesnerioides for orobanchol-type SLs, S. hermontica for strigol-type SLs, as well as some indications on a possible preference of O. cumana for non-canonical SLs. In the case of the activity on AMF growth, canonical SLs proved greater affinity, with much lower concentrations necessary to generate the same effects as most of the non-canonical type.

Regarding the germination activity in particular, some SLs showed activities over $90 \%$ even when used at low concentrations, in the range 0.1-10 nM. However, we consider that the activity of natural SLs on relevant weed species such as O. cumana, O. crenata, or P. aegyptiaca should be studied in more depth in order to increase the already known data. This would also apply to other species of AMF aside from G. margarita, the latter being especially sensible to orobanchol, 4-deoxyorobanchol, and 5-deoxystrigol (minimum effective concentration values of 1 or $3 \mathrm{pg} /$ disc).

Finally, according to the latest studies, SLs can be postulated as an attractive alternative for parasitic weed control through trap crops or suicidal germination strategies, based on the stimulatory activity showed on parasitic seed germination bioassays. The activity on hyphal branching observed can be useful in agriculture. Nonetheless, several disadvantages and limitations must be faced prior to its implementation in agriculture. In the authors' opinion, further studies that focus on overcoming some difficulties associated to the practical use of SLs would be desirable. For instance, the isolation of new canonical and non-canonical SLs and in greater quantities, focusing on the optimal growing conditions of the plants for SLs production. The stability of SLs will be an essential factor for their use in agriculture, for that, studies to improve it are necessary. 
Author Contributions: Conceptualization, F.J.S.-C., J.G.Z., C.R. and J.M.I.; methodology, C.R., J.M.G.M. and J.M.I.; software, F.J.S.-C., J.G.Z. and C.R.; validation, C.R., R.M.V., J.M.G.M., J.M.I. and F.A.M.; formal analysis, F.J.S.-C., J.G.Z., C.R. and J.M.I.; investigation, F.J.S.-C., J.G.Z. and C.R.; resources, F.A.M.; data curation, F.J.S.-C. and J.G.Z.; writing-original draft preparation, F.J.S.-C., J.G.Z. and C.R.; writing-review and editing, J.G.Z.; visualization, F.J.S.-C. and J.G.Z.; supervision, R.M.V., J.M.G.M., J.M.I. and F.A.M.; project administration, F.A.M.; funding acquisition, F.A.M. All authors have read and agreed to the published version of the manuscript.

Funding: This work was supported by the "Ministerio de Economía, Industria y Competitividad" (MINEICO), Spain, Project AGL2017-88-083-R; and by grants RTI2018-094350-B-C31 from the Spanish National R\&D Plan of the Ministry of Science, Innovation and Universities Economy and Competitiveness (MICIU) and the European Regional Development Fund (ERDF).

Institutional Review Board Statement: Not applicable.

Informed Consent Statement: Not applicable.

Data Availability Statement: The data presented in this study are available on request from the corresponding author.

Conflicts of Interest: The authors declare no conflict of interest. The funders had no role in the design of the study; in the collection, analyses, or interpretation of data; in the writing of the manuscript, or in the decision to publish the results.

\section{References}

1. Macías, F.A.; Durán, A.G.; Molinillo, J.M.G. Allelopathy: The Chemical Language of Plants. In Progress in the Chemistry of Organic Natural Products 112; Kinghorn, A.D., Falk, H., Gibbons, S., Kobayashi, J., Asakawa, Y., Liu, J., Eds.; Springer: Cham, Switzerland, 2020; pp. 1-84.

2. Pons, S.; Fournier, S.; Chervin, C.; Bécard, G.; Rochange, S.; Dit Frey, N.F.; Pagès, V.P. Phytohormone production by the arbuscular mycorrhizal fungus Rhizophagus irregularis. PLoS ONE 2020, 15, e0240886. [CrossRef] [PubMed]

3. Lang, T.; Wei, P.; Chen, X.; Fu, Y.; Tam, N.F.; Hu, Z.; Chen, Z.; Li, F.; Zhou, H. Microcosm Study on Allelopathic Effects of Leaf Litter Leachates and Purified Condensed Tannins from Kandelia obovata on Germination and Growth of Aegiceras corniculatum. Forests 2021, 12, 1000. [CrossRef]

4. Jmii, G.; Molinillo, J.M.G.; Zorrilla, J.G.; Haouala, R. Allelopathic activity of Thapsia garganica L. leaves on lettuce and weeds, and identification of the active principles. S. Afr. J. Bot. 2020, 131, 188-194. [CrossRef]

5. Sarheed, M.M.; Rajabi, F.; Kunert, M.; Boland, W.; Wetters, S.; Miadowitz, K.; Kaźmierczak, A.; Sahi, V.P.; Nick, P. Cellular Base of Mint Allelopathy: Menthone Affects Plant Microtubules. Front. Plant Sci. 2020, 11, 1320. [CrossRef] [PubMed]

6. Ćavar, S.; Zwanenburg, B.; Tarkowski, P. Strigolactones: Occurrence, structure, and biological activity in the rhizosphere. Phytochem. Rev. 2015, 14, 691-711. [CrossRef]

7. Seto, Y.; Sado, A.; Asami, K.; Hanada, A.; Umehara, M.; Akiyama, K.; Yamaguchi, S. Carlactone is an endogenous biosynthetic precursor for strigolactones. Proc. Natl. Acad. Sci. USA 2014, 111, 1640-1645. [CrossRef] [PubMed]

8. Jia, K.P.; Baz, L.; Al-Babili, S. From carotenoids to strigolactones. J. Exp. Bot. 2018, 69, 2189-2204. [CrossRef] [PubMed]

9. Bouwmeester, H.J.; Fonne-pfister, R.; Screpanti, C.; Mesmaeker, A. De Strigolactones: Plant Hormones with Promising Features. Angew. Chem. 2019, 12778-12786. [CrossRef]

10. Chesterfield, R.J.; Vickers, C.E.; Beveridge, C.A. Translation of Strigolactones from Plant Hormone to Agriculture: Achievements, Future Perspectives, and Challenges. Trends Plant Sci. 2020, 1-20. [CrossRef] [PubMed]

11. Yoneyama, K.; Brewer, P.B. Strigolactones, how are they synthesized to regulate plant growth and development? Curr. Opin. Plant Biol. 2021, 63, 102072. [CrossRef] [PubMed]

12. Cook, C.E.; Whichard, L.P.; Turner, B.; Wall, M.E.; Egley, G.H. Germination of witchweed (Striga lutea Lour.): Isolation and properties of a potent stimulant. Science (80-) 1966, 154, 1189-1190. [CrossRef] [PubMed]

13. Hauck, C.; Müller, S.; Schildknecht, H. A Germination Stimulant for Parasitic Flowering Plants from Sorghum bicolor, a Genuine Host Plant. J. Plant Physiol. 1992, 139, 474-478. [CrossRef]

14. Akiyama, K.; Matsuzaki, K.; Hayashi, H. Plant sesquiterpenes induce hyphal branching in arbuscular mycorrhizal fungi. Nature 2005, 435, 824-827. [CrossRef] [PubMed]

15. Umehara, M.; Hanada, A.; Yoshida, S.; Akiyama, K.; Arite, T.; Takeda-Kamiya, N.; Magome, H.; Kamiya, Y.; Shirasu, K.; Yoneyama, K.K.; et al. Inhibition of shoot branching by new terpenoid plant hormones. Nature 2008, 455, 195-200. [CrossRef]

16. Gomez-Roldan, V.; Fermas, S.; Brewer, P.B.; Puech-Pages, V.; Dun, E.A.; Pillot, J.-P.; Letisse, F.; Matusova, R.; Danoun, S.; Portais, J.-C.; et al. Strigolactone inhibition of shoot branching. Nature 2008, 455, 189-194. [CrossRef]

17. Prandi, C.; McErlean, C.S.P. The Chemistry of Strigolactones. In Strigolactones-Biology and Applications; Koltai, H., Prandi, C., Eds.; Springer Nature: Cham, Switzerland, 2019; pp. 163-198. 
18. Xie, X.; Yoneyama, K.; Kusumoto, D.; Yamada, Y.; Yokota, T.; Takeuchi, Y.; Yoneyama, K. Isolation and identification of alectrol as (+)-orobanchyl acetate, a germination stimulant for root parasitic plants. Phytochemistry 2008, 69, 427-431. [CrossRef] [PubMed]

19. Zwanenburg, B.; Regeling, H.; Van Tilburg-Joukema, C.W.; Van Oss, B.; Molenveld, P.; De Gelder, R.; Tinnemans, P. Securing Important Strigolactone Key Structures: Orobanchol and 5-Deoxystrigol. Eur. J. Org. Chem. 2016, 2016, 2163-2169. [CrossRef]

20. Jamil, M.; Charnikhova, T.; Houshyani, B.; van Ast, A.; Bouwmeester, H.J. Genetic variation in strigolactone production and tillering in rice and its effect on Striga hermonthica infection. Planta 2012, 235, 473-484. [CrossRef]

21. Xie, X.; Yoneyama, K.; Kisugi, T.; Uchida, K.; Ito, S.; Akiyama, K.; Hayashi, H.; Yokota, T.; Nomura, T.; Yoneyama, K. Confirming stereochemical structures of strigolactones produced by rice and tobacco. Mol. Plant 2013, 6, 153-163. [CrossRef] [PubMed]

22. Yoneyama, K.K.; Xie, X.; Yoneyama, K.K.; Kisugi, T.; Nomura, T.; Nakatani, Y.; Akiyama, K.; McErlean, C.S.P. Which Are the Major Players, Canonical or Non-Canonical Strigolactones? J. Exp. Bot. 2018, 69, 2231-2239. [CrossRef]

23. Ueno, K.; Nakashima, H.; Mizutani, M.; Takikawa, H.; Sugimoto, Y. Bioconversion of 5-deoxystrigol stereoisomers to monohydroxylated strigolactones by plants. J. Pestic. Sci. 2018, 43, 198-206. [CrossRef] [PubMed]

24. Kisugi, T.; Xie, X.; Kim, H., II.; Yoneyama, K.; Sado, A.; Akiyama, K.; Hayashi, H.; Uchida, K.; Yokota, T.; Nomura, T.; et al. Strigone, isolation and identification as a natural strigolactone from Houttuynia cordata. Phytochemistry 2013, 87, 60-64. [CrossRef] [PubMed]

25. Xie, X.; Kusumoto, D.; Takeuchi, Y.; Yoneyama, K.K.; Yamada, Y.; Yoneyama, K.K. 2'-Epi-orobanchol and solanacol, two unique strigolactones, germination stimulants for root parasitic weeds, produced by tobacco. J. Agric. Food Chem. 2007, 55, 8067-8072. [CrossRef] [PubMed]

26. Xie, X.; Yoneyama, K.; Harada, Y.; Fusegi, N.; Yamada, Y.; Ito, S.; Yokota, T.; Takeuchi, Y.; Yoneyama, K. Fabacyl acetate, a germination stimulant for root parasitic plants from Pisum sativum. Phytochemistry 2009, 70, 211-215. [CrossRef]

27. Xie, X. Structural diversity of strigolactones and their distribution in the plant kingdom. Jpn. J. Pestic. Sci. 2016, 42, 10-16. [CrossRef]

28. Tokunaga, T.; Hayashi, H.; Akiyama, K. Medicaol, a strigolactone identified as a putative didehydro-orobanchol isomer, from Medicago truncatula. Phytochemistry 2015, 111, 91-97. [CrossRef] [PubMed]

29. Alder, A.; Jamil, M.; Marzorati, M.; Bruno, M.; Vermathen, M.; Bigler, P.; Ghisla, S.; Bouwmeester, H.; Beyer, P.; Al-Babili, S. The path from $\beta$-carotene to carlactone, a strigolactone-like plant hormone. Science (80-) 2012, 335, 1348-1351. [CrossRef] [PubMed]

30. Abe, S.; Sado, A.; Tanaka, K.; Kisugi, T.; Asami, K.; Ota, S.; Kim, H., II.; Yoneyama, K.; Xie, X.; Ohnishi, T.; et al. Carlactone is converted to carlactonoic acid by MAX1 in Arabidopsis and its methyl ester can directly interact with AtD14 in vitro. Proc. Natl. Acad. Sci. USA 2014, 111, 18084-18089. [CrossRef]

31. Charnikhova, T.V.; Gaus, K.; Lumbroso, A.; Sanders, M.; Vincken, J.-P.; De Mesmaeker, A.; Ruyter-Spira, C.P.; Screpanti, C.; Bouwmeester, H.J. Zealactones. Novel natural strigolactones from maize. Phytochemistry 2017, 137, 123-131. [CrossRef] [PubMed]

32. Xie, X.; Kisugi, T.; Yoneyama, K.; Nomura, T.; Akiyama, K.; Uchida, K.; Yokota, T.; McErlean, C.S.P.; Yoneyama, K. Methyl zealactonoate, a novel germination stimulant for root parasitic weeds produced by maize. J. Pestic. Sci. 2017, 42, 58-61. [CrossRef]

33. Charnikhova, T.V.; Gaus, K.; Lumbroso, A.; Sanders, M.; Vincken, J.P.; De Mesmaeker, A.; Ruyter-Spira, C.P.; Screpanti, C.; Bouwmeester, H.J. Zeapyranolactone-A novel strigolactone from maize. Phytochem. Lett. 2018, 24, 172-178. [CrossRef]

34. Kim, H., II.; Kisugi, T.; Khetkam, P.; Xie, X.; Yoneyema, K.; Uchida, K.; Yokota, T.; Nomura, T.; McErlean, C.S.P.; Yoneyama, K. Avenaol, a germination stimulant for root parasitic plants from Avena strigosa. Phytochemistry 2014, 103, 85-88. [CrossRef]

35. Ueno, K.; Furumoto, T.; Umeda, S.; Mizutani, M.; Takikawa, H.; Batchvarova, R.; Sugimoto, Y. Heliolactone, a non-sesquiterpene lactone germination stimulant for root parasitic weeds from sunflower. Phytochemistry 2014, 108, 122-128. [CrossRef] [PubMed]

36. Woo, S.; McErlean, C.S.P. Total Synthesis and Stereochemical Confirmation of Heliolactone. Org. Lett. 2019, 21, 4215-4218. [CrossRef] [PubMed]

37. Yamamoto, S.; Atarashi, T.; Kuse, M.; Sugimoto, Y.; Takikawa, H. Concise synthesis of heliolactone, a non-canonical strigolactone isolated from sunflower. Biosci. Biotechnol. Biochem. 2020, 84, 1113-1118. [CrossRef] [PubMed]

38. Baz, L.; Mori, N.; Mi, J.; Jamil, M.; Kountche, B.A.; Guo, X.; Balakrishna, A.; Jia, K.-P.; Vermathen, M.; Akiyama, K.; et al. 3-Hydroxycarlactone, a Novel Product of the Strigolactone Biosynthesis Core Pathway. Mol. Plant 2018, 11, 1312-1314. [CrossRef] [PubMed]

39. Xie, X.; Mori, N.; Yoneyama, K.; Nomura, T.; Uchida, K.; Yoneyama, K.; Akiyama, K. Lotuslactone, a non-canonical strigolactone from Lotus japonicus. Phytochemistry 2019, 157, 200-205. [CrossRef] [PubMed]

40. Mori, N.; Sado, A.; Xie, X.; Yoneyama, K.; Asami, K.; Seto, Y.; Nomura, T.; Yamaguchi, S.; Yoneyama, K.; Akiyama, K. Chemical identification of 18-hydroxycarlactonoic acid as an LjMAX1 product and in planta conversion of its methyl ester to canonical and non-canonical strigolactones in Lotus japonicus. Phytochemistry 2020, 174, 112349. [CrossRef] [PubMed]

41. Yoneyama, K.; Akiyama, K.; Brewer, P.B.; Mori, N.; Kawano-Kawada, M.; Haruta, S.; Nishiwaki, H.; Yamauchi, S.; Xie, X.; Umehara, M.; et al. Hydroxyl carlactone derivatives are predominant strigolactones in Arabidopsis. Plant Direct 2020, 4, e00219. [CrossRef] [PubMed]

42. Ueno, K.; Nomura, S.; Muranaka, S.; Mizutani, M.; Takikawa, H.; Sugimoto, Y. Ent-2'-epi-Orobanchol and its acetate, as germination stimulants for Striga gesnerioides seeds isolated from cowpea and red clover. J. Agric. Food Chem. 2011, 59, 10485-10490. [CrossRef] 
43. Khetkam, P.; Xie, X.; Kisugi, T.; Kim, H., II.; Yoneyama, K.; Uchida, K.; Yokota, T.; Nomura, T.; Yoneyama, K. 7 $\alpha-$ and 7 $\beta-$ Hydroxyorobanchyl acetate as germination stimulants for root parasitic weeds produced by cucumber. J. Pestic. Sci. 2014, 39, 121-126. [CrossRef]

44. Wang, Z.; Dong, X.; Zheng, H.H.; Zhang, H.; Deng, X.; Chen, Y.P.; Zhu, Y.; Wu, H.H.; Xu, Y.T. Two isonardosinane-type sesquiterpenoids from Nardostachys jatamansi DC. Tetrahedron Lett. 2019, 60, 1992-1995. [CrossRef]

45. Kohlen, W.; Charnikhova, T.; Bours, R.; López-Ráez, J.A.; Bouwmeester, H. Tomato strigolactones: A more detailed look. Plant Signal Behav. 2012, 8, e22785. [CrossRef]

46. Rial, C.; Tomé, S.; Varela, R.M.; Molinillo, J.M.G.; Macías, F.A. Phytochemical study of safflower roots (Carthamus tinctorius) on the induction of parasitic plant germination and weed control. J. Chem. Ecol. 2020, 46, 871-880. [CrossRef] [PubMed]

47. Yoda, A.; Mori, N.; Akiyama, K.; Kikuchi, M.; Xie, X.; Miura, K.; Yoneyama, K.; Sato-Izawa, K.; Yamaguchi, S.; Yoneyama, K.; et al. Strigolactone biosynthesis catalyzed by cytochrome P450 and sulfotransferase in sorghum. New Phytol. 2021. [CrossRef] [PubMed]

48. Ravazzolo, L.; Trevisan, S.; Manoli, A.; Boutet-Mercey, S.; Perreau, F.; Quaggiotti, S. The Control of Zealactone Biosynthesis and Exudation is Involved in the Response to Nitrogen in Maize Root. Plant Cell Physiol. 2019, 60, 2100-2112. [CrossRef] [PubMed]

49. Rial, C.; Varela, R.M.; Molinillo, J.M.G.; Durán, A.G.; Macías, F.A. Quantification of Strigolactones. In Plant and Food Carotenoids; Rodriguez-Concepcion, M., Welsch, R., Eds.; Humana: New York, NY, USA, 2020; pp. 199-208, ISBN 9781493999521.

50. Boutet-Mercey, S.; Perreau, F.; Roux, A.; Clavé, G.; Pillot, J.-P.P.; Schmitz-Afonso, I.; Touboul, D.; Mouille, G.; Rameau, C.; Boyer, F.-D.D. Validated Method for Strigolactone Quantification by Ultra High-Performance Liquid Chromatography-Electrospray Ionisation Tandem Mass Spectrometry Using Novel Deuterium Labelled Standards. Phytochem. Anal. 2018, 29, 59-68. [CrossRef] [PubMed]

51. Rial, C.; Varela, R.M.; Molinillo, J.M.G.; López-Ráez, J.A.; Macías, F.A. A new UHPLC-MS/MS method for the direct determination of strigolactones in root exudates and extracts. Phytochem. Anal. 2019, 30, 110-116. [CrossRef] [PubMed]

52. Floková, K.; Shimels, M.; Andreo Jimenez, B.; Bardaro, N.; Strnad, M.; Novák, O.; Bouwmeester, H.J. An improved strategy to analyse strigolactones in complex sample matrices using UHPLC-MS/MS. Plant Methods 2020, 16, 125. [CrossRef]

53. Halouzka, R.; Zeljković, S.Ć.; Klejdus, B.; Tarkowski, P. Analytical methods in strigolactone research. Plant Methods 2020, 16, 76 [CrossRef] [PubMed]

54. Cochetel, N.; Météier, E.; Merlin, I.; Hévin, C.; Pouvreau, J.B.; Coutos-Thévenot, P.; Hernould, M.; Vivin, P.; Cookson, S.J.; Ollat, N.; et al. Potential contribution of strigolactones in regulating scion growth and branching in grafted grapevine in response to nitrogen availability. J. Exp. Bot. 2018, 69, 4099-4112. [CrossRef] [PubMed]

55. Aquino, B.; Bradley, J.M.; Lumba, S. On the outside looking in: Roles of endogenous and exogenous strigolactones. Plant J. 2021, 105, 322-334. [CrossRef] [PubMed]

56. Borghi, L.; Kang, J.; de Brito Francisco, R. Filling the gap: Functional clustering of ABC proteins for the investigation of hormonal transport in planta. Front. Plant Sci. 2019, 10, 422. [CrossRef]

57. Zorrilla, J.G.; Cala, A.; Rial, C.; Mejías, F.J.R.; Molinillo, J.M.G.; Varela, R.M.; Macías, F.A. Synthesis of Active Strigolactone Analogues Based on Eudesmane- and Guaiane-Type Sesquiterpene Lactones. J. Agric. Food Chem. 2020, 68, 9636-9645. [CrossRef] [PubMed]

58. Hasan, M.N.; Razvi, S.S.I.; Kuerban, A.; Balamash, K.S.; Al-Bishri, W.M.; Abulnaja, K.O.; Choudhry, H.; Khan, J.A.; Moselhy, S.S.; Ma, Z.; et al. Strigolactones-A novel class of phytohormones as anti-cancer agents. J. Pestic. Sci. 2018, 43, 168-172. [CrossRef] [PubMed]

59. Tian, M.Q.; Jiang, K.; Takahashi, I.; Li, G.D. Strigolactone-induced senescence of a bamboo leaf in the dark is alleviated by exogenous sugar. J. Pestic. Sci. 2018, 43, 173-179. [CrossRef]

60. Hu, Q.; Ding, F.; Li, M.; Zhang, X.; Zhang, S.; Huang, B. Strigolactone and ethylene inhibitor suppressing dark-induced leaf senescence in perennial ryegrass involving transcriptional downregulation of chlorophyll degradation. J. Am. Soc. Hortic. Sci. 2021, 146, 79-86. [CrossRef]

61. Takahashi, I.; Jiang, K.; Asami, T. Counteractive effects of sugar and strigolactone on leaf senescence of rice in darkness. Agronomy 2021, 11, 1044. [CrossRef]

62. Rubiales, D.; Fernández-Aparicio, M.; Wegmann, K.; Joel, D.M. Revisiting strategies for reducing the seedbank of Orobanche and Phelipanche spp. Weed Res. 2009, 49, 23-33. [CrossRef]

63. Macías, F.A.; Mejías, F.J.; Molinillo, J.M. Recent advances in allelopathy for weed control: From knowledge to applications. Pest Manag. Sci. 2019, 75, 2413-2436. [CrossRef]

64. Zorrilla, J.G.; Rial, C.; Varela, R.M.; Molinillo, J.M.G.; Macías, F.A. Facile synthesis of anhydrojudaicin and 11,13dehydroanhydrojudaicin, two eudesmanolide-skeleton lactones with potential allelopathic activity. Phytochem. Lett. 2019, 31, 229-236. [CrossRef]

65. Lumbroso, A.; Villedieu-Percheron, E.; Zurwerra, D.; Screpanti, C.; Lachia, M.; Dakas, P.Y.; Castelli, L.; Paul, V.; Wolf, H.C.; Sayer, D.; et al. Simplified strigolactams as potent analogues of strigolactones for the seed germination induction of Orobanche cumana Wallr. Pest Manag. Sci. 2016, 72, 2054-2068. [CrossRef]

66. Pouvreau, J.-B.; Poulin, L.; Huet, S.; Delavault, P. Strigolactone-Like Bioactivity via Parasitic Plant Germination Bioassay. In Strigolactones; Cardinale, F., Prandi, C., Eds.; Humana: New York, NY, USA; pp. 59-74. ISBN 9781071614280. 
67. Evidente, A.; Fernández-Aparicio, M.; Cimmino, A.; Rubiales, D.; Andolfi, A.; Motta, A. Peagol and peagoldione, two new strigolactone-like metabolites isolated from pea root exudates. Tetrahedron Lett. 2009, 50, 6955-6958. [CrossRef]

68. Yoneyama, K. Recent progress in the chemistry and biochemistry of strigolactones. J. Pestic. Sci. 2020, 45, 45-53. [CrossRef] [PubMed]

69. Nomura, S.; Nakashima, H.; Mizutani, M.; Takikawa, H.; Sugimoto, Y. Structural requirements of strigolactones for germination induction and inhibition of Striga gesnerioides seeds. Plant Cell Rep. 2013, 32, 829-838. [CrossRef] [PubMed]

70. Cook, C.; Whichard, L.; Wall, M.; Egley, G. Germination stimulants. II. Structure of strigol, a potent seed germination stimulant for witchweed (Striga lutea). J. Am. Chem. Soc. 1972, 94, 6198-6199. [CrossRef]

71. Kim, H., II.; Xie, X.; Kim, H.S.; Chun, J.C.; Yoneyama, K.; Nomura, T.; Takeuchi, Y.; Yoneyama, K. Structure-activity relationship of naturally occurring strigolactones in Orobanche minor seed germination stimulation. J. Pestic. Sci. 2010, 35, 344-347. [CrossRef]

72. Sugimoto, Y.; Ueyama, T. Production of (+)-5-deoxystrigol by Lotus japonicus root culture. Phytochemistry 2008, 69, 212-217. [CrossRef] [PubMed]

73. Ueno, K.; Fujiwara, M.; Nomura, S.; Mizutani, M.; Sasaki, M.; Takikawa, H.; Sugimoto, Y. Structural requirements of strigolactones for germination induction of Striga gesnerioides seeds. J. Agric. Food Chem. 2011, 59, 9226-9231. [CrossRef] [PubMed]

74. Matsuura, H.; Ohashi, K.; Sasako, H.; Tagawa, N.; Takano, Y.; Ioka, Y.; Nabeta, K.; Yoshihara, T. Germination stimulant from root exudates of Vigna unguiculata. Plant Growth Regul. 2008, 54, 31-36. [CrossRef]

75. Xie, X.; Yoneyama, K.; Kurita, J.; Harada, Y.; Yamada, Y.; Takeuchi, Y.; Yoneyama, K. 7-Oxoorobanchyl acetate and 7-Oxoorobanchol as germination stimulants for root parasitic plants from flax (Linum usitatissimum). Biosci. Biotechnol. Biochem. 2009, 73, 1367-1370. [CrossRef]

76. Yoshimura, M.; Fonné-Pfister, R.; Screpanti, C.; Hermann, K.; Rendine, S.; Dieckmann, M.; Quinodoz, P.; De Mesmaeker, A. Total Synthesis and Biological Evaluation of Heliolactone. Helv. Chim. Acta 2019, 102. [CrossRef]

77. Lachia, M.; Wolf, H.C.; De Mesmaeker, A. Synthesis of strigolactones analogues by intramolecular [2+2] cycloaddition of keteneiminium salts to olefins and their activity on Orobanche cumana seeds. Bioorg. Med. Chem. Lett. 2014, 24, 2123-2128. [CrossRef] [PubMed]

78. Ashida, K.; Hoshimoto, Y.; Tohnai, N.; Scott, D.E.; Ohashi, M.; Imaizumi, H.; Tsuchiya, Y.; Ogoshi, S. Enantioselective Synthesis of Polycyclic $\gamma$-Lactams with Multiple Chiral Carbon Centers via Ni(0)-Catalyzed Asymmetric Carbonylative Cycloadditions without Stirring. J. Am. Chem. Soc. 2020, 142, 1594-1602. [CrossRef] [PubMed]

79. Ronellenfitsch, H.; Liesche, J.; Jensen, K.H.; Michele Holbrook, N.; Schulz, A.; Katifori, E. Scaling of phloem structure and optimality of photoassimilate transport in conifer needles. Proc. R. Soc. B Biol. Sci. 2015, 282. [CrossRef]

80. Cardoso, C.; Ruyter-Spira, C.; Bouwmeester, H.J. Strigolactones and root infestation by plant-parasitic Striga, Orobanche and Phelipanche spp. Plant Sci. 2011, 180, 414-420. [CrossRef] [PubMed]

81. Wang, Y.; Duran, H.G.S.; van Haarst, J.C.; Schijlen, E.G.W.M.; Ruyter-Spira, C.; Medema, M.H.; Dong, L.; Bouwmeester, H.J. The role of strigolactones in P deficiency induced transcriptional changes in tomato roots. BMC Plant Biol. 2021, 21, 1-21. [CrossRef] [PubMed]

82. Banasiak, J.; Borghi, L.; Stec, N.; Martinoia, E.; Jasiński, M. The Full-Size ABCG Transporter of Medicago truncatula Is Involved in Strigolactone Secretion, Affecting Arbuscular Mycorrhiza. Front. Plant Sci. 2020, 11, 18. [CrossRef]

83. Abdelhalim, T.; Jannoura, R.; Joergensen, R.G. Mycorrhiza response and phosphorus acquisition efficiency of sorghum cultivars differing in strigolactone composition. Plant Soil 2019, 437, 55-63. [CrossRef]

84. Zhou, Y.; Ge, S.; Jin, L.; Yao, K.; Wang, Y.; Wu, X.; Zhou, J.; Xia, X.; Shi, K.; Foyer, C.H.; et al. A novel CO ${ }_{2}$-responsive systemic signaling pathway controlling plant mycorrhizal symbiosis. New Phytol. 2019, 224, 106-116. [CrossRef] [PubMed]

85. López-Ráez, J.A. How drought and salinity affect arbuscular mycorrhizal symbiosis and strigolactone biosynthesis? Planta 2016, 243, 1375-1385. [CrossRef] [PubMed]

86. Kong, C.C.; Ren, C.G.; Li, R.Z.; Xie, Z.H.; Wang, J.P. Hydrogen Peroxide and Strigolactones Signaling Are Involved in Alleviation of Salt Stress Induced by Arbuscular Mycorrhizal Fungus in Sesbania cannabina Seedlings. J. Plant Growth Regul. 2017, 36, 734-742. [CrossRef]

87. Ruth, B.; Khalvati, M.; Schmidhalter, U. Quantification of Mycorrhizal water uptake via high-resolution on-line water content sensors. Plant Soil 2011, 342, 459-468. [CrossRef]

88. Nasir, F.; Shi, S.; Tian, L.; Chang, C.; Ma, L.; Li, X.; Gao, Y.; Tian, C. Strigolactones shape the rhizomicrobiome in rice (Oryza sativa). Plant Sci. 2019, 286, 118-133. [CrossRef]

89. Mitra, D.; Guerra Sierra, B.E.; Khoshru, B.; De Los Santos Villalobos, S.; Belz, C.; Chaudhary, P.; Shahri, F.N.; Djebaili, R.; Adeyemi, N.O.; El-Ballat, E.M.; et al. Impacts of Arbuscular Mycorrhizal Fungi on Rice Growth, Development, and Stress Management With a Particular Emphasis on Strigolactone Effects on Root Development. Commun. Soil Sci. Plant Anal. 2021, 52, 1591-1621. [CrossRef]

90. Akiyama, K.; Ogasawara, S.; Ito, S.; Hayashi, H. Structural requirements of strigolactones for hyphal branching in AM fungi. Plant Cell Physiol. 2010, 51, 1104-1117. [CrossRef]

91. Mori, N.; Nishiuma, K.; Sugiyama, T.; Hayashi, H.; Akiyama, K. Carlactone-type Strigolactones and their Synthetic Analogues as Inducers of Hyphal Branching in Arbuscular Mycorrhizal Fungi. Phytochemistry 2016, 130, 90-98. [CrossRef] [PubMed] 
92. Besserer, A.; Puech-Pagès, V.; Kiefer, P.; Gomez-Roldan, V.; Jauneau, A.; Roy, S.; Portais, J.C.; Roux, C.; Bécard, G.; Séjalon-Delmas, N. Strigolactones stimulate arbuscular mycorrhizal fungi by activating mitochondria. PLoS Biol. 2006, 4, 1239-1247. [CrossRef] [PubMed]

93. López-Raez, J.A.; Shirasu, K.; Foo, E. Strigolactones in Plant Interactions with Beneficial and Detrimental Organisms: The Yin and Yang. Trends Plant Sci. 2017, 22, 527-537. [CrossRef] [PubMed]

94. Parker, C.; Riches, C.R. Parasitic Weeds of the World: Biology and Control; CAB International: Wallingford, UK, 1993.

95. Chai, M.; Zhu, X.; Cui, H.; Jiang, C.; Zhang, J.; Shi, L. Lily Cultivars Have Allelopathic Potential in Controlling Orobanche aegyptiaca Persoon. PLoS ONE 2015, 10, e0142811. [CrossRef]

96. Vurro, M.; Boari, A.; Thiombiano, B.; Bouwmeester, H. Strigolactones and Parasitic Plants. In Strigolactones-Biology and Applications; Koltai, H., Prandi, C., Eds.; Springer: Cham, Switzerland, 2019; pp. 89-120.

97. Nelson, D.C. The mechanism of host-induced germination in root parasitic plants. Plant Physiol. 2021, 185, 1353-1373. [CrossRef] [PubMed]

98. Zwanenburg, B.; Pospíšil, T.; Ćavar Zeljković, S. Strigolactones: New plant hormones in action. Planta 2016, 243, 1311-1326. [CrossRef] [PubMed]

99. Bürger, M.; Chory, J. The Many Models of Strigolactone Signaling. Trends Plant Sci. 2020, 25, 395-405. [CrossRef]

100. Hailu, G.; Niassy, S.; Zeyaur, K.R.; Ochatum, N.; Subramanian, S. Maize-legume intercropping and push-pull for management of fall armyworm, stemborers, and Striga in Uganda. Agron. J. 2018, 110, 2513-2522. [CrossRef]

101. Yoneyama, K.; Xie, X.; Yoneyama, K.; Nomura, T.; Takahashi, I.; Asami, T.; Mori, N.; Akiyama, K.; Kusajima, M.; Nakashita, H. Regulation of biosynthesis, perception, and functions of strigolactones for promoting arbuscular mycorrhizal symbiosis and managing root parasitic weeds. Pest Manag. Sci. 2019, 75, 2353-2359. [CrossRef] [PubMed]

102. Kawada, K.; Takahashi, I.; Arai, M.; Sasaki, Y.; Asami, T.; Yajima, S.; Ito, S. Synthesis and Biological Evaluation of Novel Triazole Derivatives as Strigolactone Biosynthesis Inhibitors. J. Agric. Food Chem. 2019, 67, 6143-6149. [CrossRef] [PubMed]

103. Bao, Y.Z.; Yao, Z.Q.; Cao, X.L.; Peng, J.F.; Xu, Y.; Chen, M.X.; Zhao, S.F. Transcriptome analysis of Phelipanche aegyptiaca seed germination mechanisms stimulated by fluridone, TIS108, and GR24. PLoS ONE 2017, 12, e0187539. [CrossRef] [PubMed]

104. Holbrook-Smith, D.; Toh, S.; Tsuchiya, Y.; McCourt, P. Small-molecule antagonists of germination of the parasitic plant Striga hermonthica. Nat. Chem. Biol. 2016, 12, 724-729. [CrossRef] [PubMed]

105. Khosla, A.; Nelson, D.C. Strigolactones, super hormones in the fight against Striga. Curr. Opin. Plant Biol. $2016,33,57-63$. [CrossRef] 